OPEN ACCESS

Edited by:

Cecile Guieu,

Centre National de la Recherche

Scientifique, France

Reviewed by:

Arvind Singh,

Physical Research Laboratory, India

Loes Gerringa,

Royal Netherlands Institute for Sea

Research (NWO), Netherlands

Randelle M. Bundy,

Woods Hole Oceanographic

Institution, USA

*Correspondence:

Christel S. Hassler

christel.hassler@unige.ch

Specialty section: This article was submitted to Marine Biogeochemistry, a section of the journal

Frontiers in Marine Science

Received: 23 September 2016

Accepted: 16 January 2017

Published: 01 February 2017

Citation:

Hassler CS, van den Berg CMG and Boyd PW (2017) Toward a Regional

Classification to Provide a More Inclusive Examination of the Ocean Biogeochemistry of Iron-Binding Ligands. Front. Mar. Sci. 4:19. doi: 10.3389/fmars.2017.00019

\section{Toward a Regional Classification to Provide a More Inclusive Examination of the Ocean Biogeochemistry of Iron-Binding Ligands}

\author{
Christel S. Hassler ${ }^{1 *}$, Constant M. G. van den Berg ${ }^{2}$ and Philip W. Boyd ${ }^{3}$ \\ ${ }^{1}$ Marine and Lake Biogeochemistry, Department F.-A. Forel, University of Geneva, Geneva, Switzerland, ${ }^{2}$ School of \\ Environmental Sciences, University of Liverpool, Liverpool, UK, ${ }^{3}$ Institute for Marine and Antarctic Studies, University of \\ Tasmania, Hobart, TAS, Australia
}

Iron-binding ligands are paramount to understanding iron biogeochemistry and its potential to set the productivity and the magnitude of the biological pump in $>30 \%$ of the ocean. However, the nature of these ligands is largely uncharacterized and little is known about their sources, sensitivity to photochemistry and biological transformation, or scavenging behavior. Despite many uncertainties, there is no doubt that ligands are produced by a wide range of biotic and abiotic processes, and that the bulk ligand pool encompasses a diverse range of molecules. Despite widespread recognition of the likelihood of a continuum of ligand classes making up the bulk ligand pool, studies to date largely focused on the dominant ligand. Thus, most studies have overlooked the need to assess where these targeted molecules fit across the spectrum of ligands that comprise the bulk ligand pool. Here we summarize present knowledge to critically assess the source(s), function(s), production pathways, and loss mechanisms of three important iron-binding organic ligand groups in order to assess their distinctive characteristics and how they link with observed ligand distributions. We considered that ligands are contained in broad groupings of exopolymer substances (EPS), humic substances (HS), and siderophores; using literature data for speciation modeling suggested that this adequately described the iron speciation reported in the ocean. We hypothesize that a holistic viewpoint of the multi-faceted controls on ligands dynamics is essential to begin to understand why some ligands can be expected to dominate in particular oceanic regions, depth strata, or exhibit seasonality and/or lateral gradients. We advocate that the development of a regional classification will enhance our understanding of the changing composition of the bulk ligand pool across the global ocean and to help address to what extent seasonality influences the makeup of this pool. This classification, based on selected functional ligand classes, can act as a bridge to use future ligand datasets to fill in the gaps in the continuum.

Keywords: iron, exopolymeric substances, humics, organic ligands, oceanic distribution 


\section{INTRODUCTION}

In marine systems, more than $99.9 \%$ of dissolved $\mathrm{Fe}$ is associated with dissolved organic complexing ligands (Rue and Bruland, 1995; van den Berg, 1995) a component of the dissolved organic carbon (DOC) pool. Fe-binding organic ligands are essential for the functioning of the oceanic Fe cycle, enhancing the solubility of iron (Kuma et al., 1998; Schlosser et al., 2012) influencing its reactivity (i.e., defined here as chemical stability and accessibility to the biota), and hence availability to support phytoplankton growth (Maldonado et al., 2005; Hassler et al., 2011b, 2012). During the last three decades, research have revealed numerous and complex interactions between Fe chemistry and biology including inextricable linkages with ligands across the entire water column (Boyd and Ellwood, 2010; Gledhill and Buck, 2012). However, as highlighted by a recent Working Group funded by the Scientific Committee for Oceanic Research (SCOR, WG139, Organic ligands-a key control on trace metal biogeochemistry in the ocean, http://neon.otago.ac.nz/research/ scor/), the composition and origin of Fe-binding organic ligands remain mostly unknown.

The use of proxies for iron binding ligands, such as bulk DOC concentrations, is an approach that was employed initially but was unable to predict Fe solubility and its global distribution (Völker and Tagliabue, 2015). Therefore, iron biogeochemical models are developing by considering organic ligands production and loss terms to reconcile model outputs with observations (Völker and Tagliabue, 2015). The identification of which fraction of the DOC pool (englobing its sources production pathways, solubility, molecular weight, or other chemical characteristics) most influences Fe biogeochemistry is one of the major analytical obstacles in the field of marine biogeochemistry (Benner, 2011).
The conditional stability and the distribution of iron-binding organic ligands provide a means of demarcating different groups of ligands. Since 1994 (Gledhill and van den Berg, 1994), electrochemistry has been used to measure the concentration of Fe-binding ligands (L) and their conditional stability constants $\left(\log \mathrm{K}_{\mathrm{Fe}^{\prime} \mathrm{L}} \mathrm{L}\right.$ both of which are important to define their impact on Fe biogeochemistry (Gledhill and Buck, 2012). Recent studies on iron chemical speciation have now revealed that the vertical zonation of organic ligands - with stronger ligands ( $\mathrm{L}_{1}$-type, log $\left.\mathrm{K}_{\mathrm{Fe}^{\prime} \mathrm{L}} \geq 12-13\right)$ observed in surface waters, when present, and weaker $\left(\mathrm{L}_{2}-\right.$ to $\mathrm{L}_{4}$-type, $\log \mathrm{K}_{\mathrm{Fe}^{\prime} \mathrm{L}} 10-12$, and probably $<10$ ) throughout the water column-proposed by Hunter and Boyd (2007), was not consistent. Indeed, in the Atlantic Ocean, $\mathrm{L}_{1}$ are reported throughout the water column (Buck et al., 2015; Gerringa et al., 2015, Figure 1A).

The concentration of Fe-binding ligands tends to be greater and shows most variability in surface waters, with peaks often found co-located with the subsurface chlorophyll maximum implying both a strong relationship with biological activity (Gledhill and Buck, 2012; Gerringa et al., 2015; Bundy et al., 2016) and rapid ligand turnover comparable to that reported for labile DOC (Hansell, 2013). Ligand turnover rates may potentially be derived from variability of organic ligand concentrations in depth profiles or seasonal studies, but in most cases, there are insufficient data to constrain turnover estimates. Recently, a 1000 year residence time was estimated for organic ligands in the North Atlantic Deep Water (NADW) (Gerringa et al., 2015), suggesting that ligands at depth are different from those in surface waters. Furthermore, this relatively large residence time means they can persist longer than dissolved iron (e.g., inorganic and organic iron chemical species below a $0.2-0.45$ micron operational cut-off) and their longevity points to them
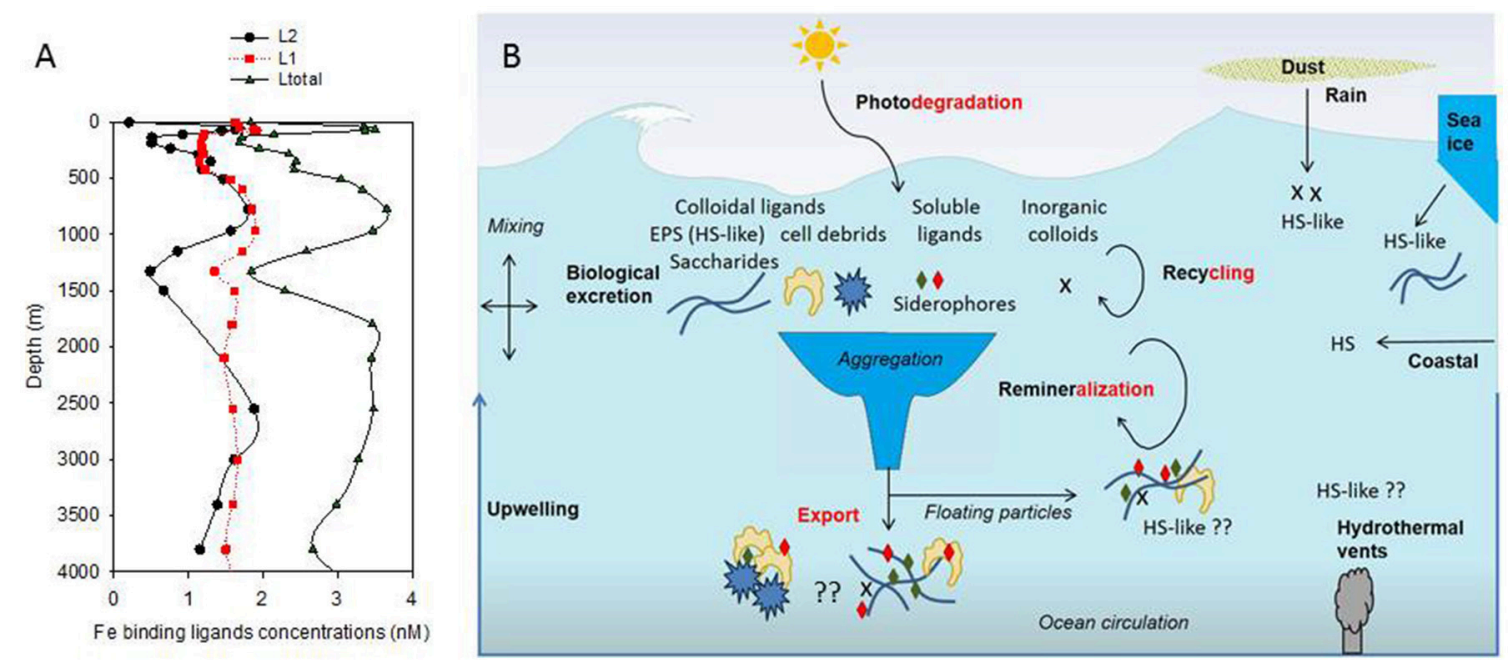

FIGURE 1 | Vertical distribution of organic ligands (from Buck et al., 2015, Stn 18, Atlantic Ocean, $24.15^{\circ} \mathrm{N}, \mathbf{4 0 . 2 2}^{\circ} \mathrm{W}$; A); Showing strong ligands $\left(\mathrm{L}_{1}\right.$, average $\log \mathrm{K}_{\mathrm{Fe}^{\prime} \mathrm{L} 1}$ of 12.42), weaker ligands ( $\mathrm{L}_{2}$, average $\log \mathrm{K}_{\mathrm{Fe}^{\prime} \mathrm{L} 2}$ of 11.20$)$ and total detected ligands concentrations ( $\left.\mathrm{L}_{\text {tot }}\right)$. Predicted ligands composition was derived from a conceptual representation (B) of organic ligands sources (black bold) and loss (red bold) with differentiation between terrestrial humics (HS), marine humics (HS-like) originating from biological excretion (EPS) and from recycling and remineralisation as well as soluble ligands which include siderophore. Putative processes or ligand sources are marked by "??." 
being potentially reused, recycled, and/or refractory in nature and influence by ocean circulation. Based on our current understanding of external sources in addition to in-situ processes involved in ligand production (Table 1, Figure 1B; Gledhill and Buck, 2012), the case for different ligands is compelling. In the upper water column, a causal linkage can be made between organic ligands and the production of siderophores (which have conditional stability constants comparable to or considerably greater) than $\mathrm{L}_{1}$ ligands (MacRellis et al., 2001), and bacterial/algal exudates associated with biological activity (Benner, 2011; Hassler et al., 2011a; Norman et al., 2015; Figure 1B). Phytoplankton can release several ligands including domoic acid, exopolymeric substances (EPS), and saccharides (Maldonado et al., 2002; Hassler et al., 2011b; Norman et al., 2015), thiols and phytochelatins (Leal et al., 1999; Dupont et al., 2004, 2006). This ligand distribution is superimposed on a background "profile" of ligands derived from the breakdown of biogenic particles (Boyd et al., 2010), particle-associated siderophores (likely at very low concentration) associated with particle-attached bacteria (Azam and Malfatti, 2007; Cordero et al., 2012), and other plant-derived organic matter. Generic cellular debris will ultimately be broken down by microbes (Letscher et al., 2011) to leave less labile dissolved organic matter such as humic material of marine origin (Figure 1B; Hansell, 2013). These humics would add to the pool of humic material from terrestrial origin entering the ocean (Moran et al., 2016). The ligands associated with particle breakdown tend to have lower conditional stability constants-more akin to $\mathrm{L}_{2}-\mathrm{L}_{4}$ (Boyd et al., 2010; Bundy et al., 2015), and are observed throughout the water column (Gledhill and Buck, 2012; Hassler et al., 2012; Buck et al., 2015). Hence, three distinct groups of ligands stand out as potentially critical ones for iron biogeochemistry: siderophores, biological degradation/excretion products, and humics.

We focus here on distinctive characteristics (distribution, function, source, and distribution) of the three major ligand groups, in order to identify whether there are oceanic regions and/or strata in which particular organic ligands dominate. We then assess if this could be used to develop an oceanwide classification and a holistic approach to understanding multi-faceted controls on ligands. To explore whether such a demarcation is possible, and its potential applications (such as driving targeted research on specific aspects of ligands), we distinguish and focus on organic ligands with different production and loss pathways, functions, and reactivity, likely to result in differences in their distribution across the ocean. The first group of ligand are humics substances, which are loosely-defined macromolecules. Here, we subdivided humics into several sub-groups based on their origins and production pathways, distinguishing terrestrial (HS) from marine humics (HS-like). Because of differing biological production pathways, fates, location, and stability of ligands in marine waters we further differentiate HS-like associated with refractory DOM and biological production of labile DOM as HS-like associated with remineralization and biological excretion, respectively (Table 1, Figure 1B). The second group of ligands, siderophores, are small molecules excreted by heterotrophic and cyano-bacteria in response to iron limitation. The third group of organic ligands are biological degradation/excretion products at large (e.g., not restricted to bacterial origin and not necessarily specific to Fe limitation), comprising exopolymeric substances and polysaccharides as dominant compounds. Ultimately, our study explores the putative composition and variability of the bulk ligand pool (i.e., an extension to all ligand classes beyond the so called "ligand soup" of weaker ligands (typically assigned to $\mathrm{L}_{2}-\mathrm{L}_{4}$ classes; Hunter and Boyd, 2007) in surface vs. subsurface waters, and from near-shore to offshore regions.

We hypothesize that the differences in the sources, turnover rate, production loss pathways can be used to differentiate marine regions where HS, EPS, and siderophores are expected to dominate Fe biogeochemistry. If it is so, we will discuss how the differences in iron binding conditional stability constants amongst these three groups of ligands is at present inconsistent with the concept of a continuum of organic ligands. We will then place this knowledge in a bigger picture to explore geographical and seasonal differences in the distribution of HS (and HSlike), EPS and siderophores, at regional scales including coastal, offshore, open ocean, and upwelling regions. Finally, we will explore biogeochemical consequences of the co-occurrence of these three groups of ligands by modeling Fe chemical speciation at three boundary conditions.

Such a generic approach aims to improve our conceptual understanding of how the multiple provenances of iron-binding ligands control biogeochemistry in different ocean regions, and whether they represent a continuum in iron-binding "potential." This approach can provide a valuable platform for further research and a useful link to the global GEOTRACES survey (www.geotraces.org). We acknowledge that each of the ligand groups we are considering can be highly diverse (e.g., a wide range of siderophores, see Gledhill and Buck, 2012; Hassler et al., 2012 for reviews), and that techniques currently used for their analytical detection suggest an overlap between HSlike and HS, and HS-like and EPS (see Section Organic Ligands Distribution-Sources, Production, and Loss Pathways). Finally we acknowledge, that many more individual ligands, see (Boiteau and Repeta, 2015; Moran et al., 2016), and ligand classes remain to be characterized and identified as we move beyond these three nominal classes toward a continuum of ligands.

\section{ORGANIC LIGANDS DISTRIBUTION-SOURCES, PRODUCTION, AND LOSS PATHWAYS}

Evidence of the wide-ranging reactivity (i.e., labile, recalcitrant, refractory) of the DOC pool (Verdugo et al., 2004), combined with the current lack of detailed chemical resolution of DOC analytical techniques, have led to the suggestion that a continuum of Fe-binding organic ligands exists (Koopal et al., 2005). There is however a significant hysteresis in conditional stability constants between ligands associated with HS, breakdown products (HS-like from remineralization) and exuded material (EPS, HS-like from biological excretion), saccharides and siderophores, that enables demarcation between different groups of ligands (Table 1). These data suggest that there may 
TABLE 1 | Summary of the different iron-binding organic ligands likely to be found in marine systems.

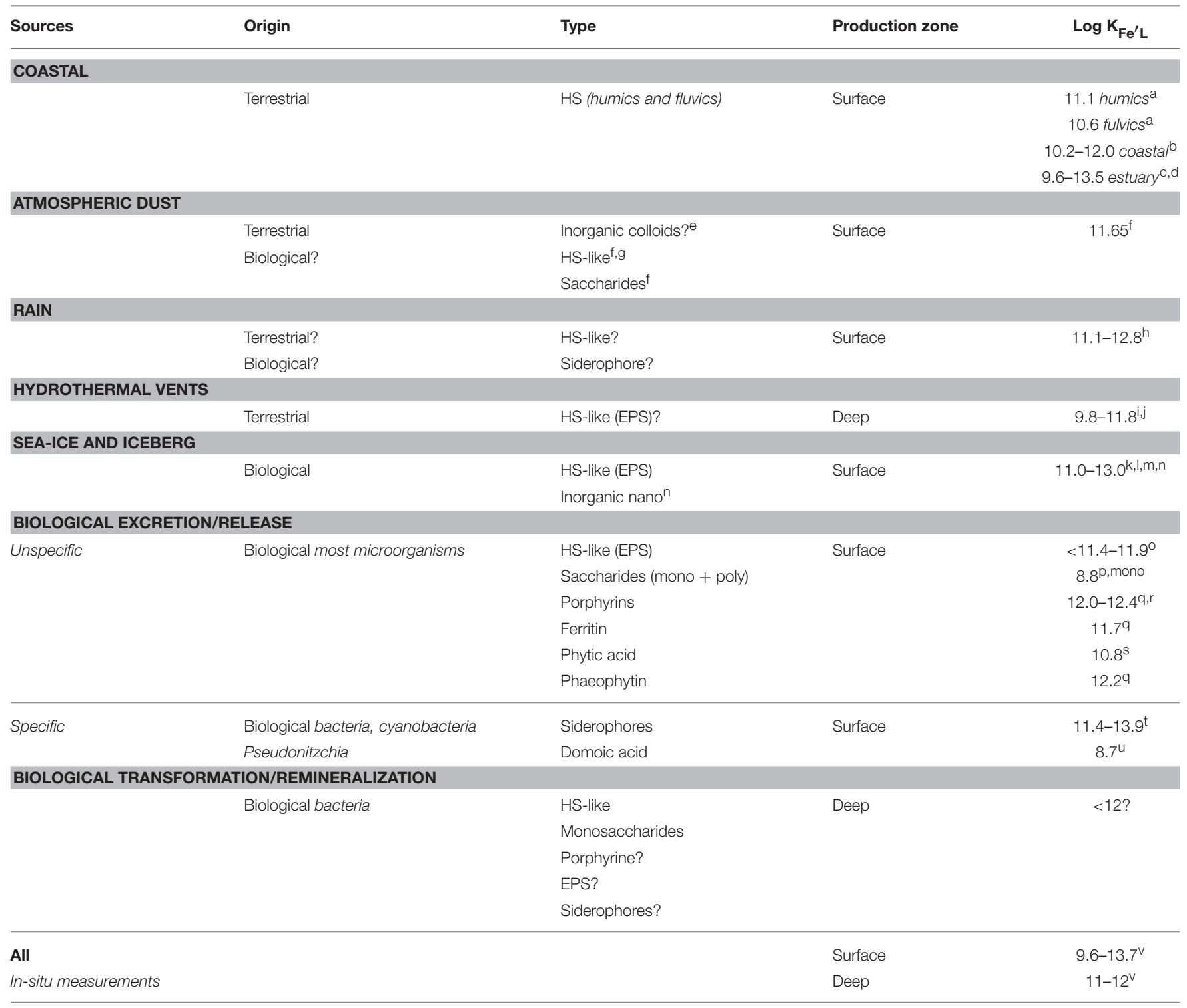

Source, origin, and conditional stability constant for iron-binding $\left(\log K_{F e^{\prime}}\right)$ are shown in addition of putative type and production zone within the water column.

aLaglera and van den Berg, 2009.

${ }^{b}$ Batchelli et al., 2010.

'Gobler et al., 2002.

${ }^{d}$ Gerringa et al., 2007.

e Fitzsimmons et al., 2015.

${ }^{f}$ Hassler and Norman, unpublished data.

gParis and Desboeufs, 2013.

${ }^{h}$ Cheize et al., 2012

iHawkes et al., 2013.

iNichols et al., 2005.

kBoye et al., 2001.

Ivan der Merwe et al., 2009.

$m_{\text {Lannuzel et al., } 2015 .}$

"Lin and Twining, 2012

o Norman et al., 2015.

${ }^{p}$ Croot and Johansson, 2000.

qWitter et al., 2000.

'Bruland et al., 2005.

sMaldonado et al., 2005.

${ }^{t}$ Hassler et al., 2012.

"Rue and Bruland, 2001.

v Gledhill and Buck, 2012. 
be a co-occurrence of extremely weak ligands (saccharides, $\mathrm{L}_{3}$ and $\mathrm{L}_{4}$ ), a group of ligands with very similar complex stability comprising HS, HS-like, EPS, and hemes $\left(\mathrm{L}_{1}-\mathrm{L}_{3}\right)$, whereas siderophores have $\log \mathrm{K}_{\mathrm{Fe}^{\prime} \mathrm{L}}$ values of $\sim 12.2$ and higher $\left(\mathrm{L}_{1}\right)$, i.e., indicative that there is not, presently, a continuum of conditional stability constants. More likely this trend results from a lack of resolution of the existing speciation methods ( $\log \mathrm{K}_{\mathrm{Fe}^{\prime} \mathrm{L}}$ values \pm 0.3 ; Gerringa et al., 2014), different outcomes across a range of speciation procedures (TAC vs. SA for instance), and the effect of not measuring speciation under equilibrium conditions. Moreover, inter-dependency between values for ligand concentration and $\mathrm{K}_{\mathrm{Fe}^{\prime} \mathrm{L}}$ may also contribute to an analytical bias, as an underestimation of the ligand concentration leads to overestimation of $\mathrm{K}_{\mathrm{Fe}^{\prime} \mathrm{L}}$ and vice versa (Hudson et al., 2003; Gerringa et al., 2014). An emerging combination of analytical approaches and evolving conceptual theories is beginning to advance this research field (e.g., Cordero et al., 2012; Boiteau and Repeta, 2015; Boyd and Tagliabue, 2015; Waska et al., 2016).

For most of the ocean the concentration of dissolved organic ligands exceeds that of dissolved iron (Gledhill and Buck, 2012; Boyd and Tagliabue, 2015) by around $1 \mathrm{nmol} \mathrm{L}-1$, suggesting a tight coupling between the iron and its complex pair. As different Fe sources are linked to distinctive ligands, such as seaice melt (Table 1), it is expected that the spatial variability of iron sources matches the variability of organic ligands, providing that in-situ recycling and biological activity are not dominating the pool of organic ligands (Figure 1B). Globally, the largest input of iron into the oceans was initially reported to come from atmospheric dust deposition (Duce and Tindale, 1991; Jickells et al., 2014) although this view has been subsequently challenged and overturned with hydrothermal and sedimentary sources being reported as more dominant, especially at high latitudes (Tagliabue et al., 2014; Resing et al., 2015). Other modes of iron supply include upwelling, coastal regions with large riverine and sedimentary inputs (Coale et al., 1996), and the cryosphere (Boyd et al., 2012). Unsurprisingly, iron-binding ligands were found in most of these iron sources (Figure 1B, Table 1): including sea-ice and icebergs (EPS, i.e., HS-like from bacterial excretion; van der Merwe et al., 2009), rainwater and dust (HS-like, saccharides), hydrothermal vents (HS and HSlike from bacterial excretion; Kleint et al., 2016), and refractory organic compounds that accumulate at depth (HS and HS-like from bacterial remineralization; Boyd et al., 2010; Heller et al., 2013; Medeiros et al., 2016). Therefore, regional and seasonal variations of the input of organic ligands within the euphotic zone are expected (see Section Toward a Map of Iron-Binding Ligand Distributions). External supply of iron and organic ligands may also result in additional ligand enrichment via the stimulation of in-situ biological production of organic ligands in surface waters (Wagener et al., 2008; Adly et al., 2015).

Indeed, the distribution of Fe-binding organic ligands in oceanic surface waters is consistent with multiple biological sources associated with biological Fe-stress, the recycling of organic carbon in surface waters (Gledhill and Buck, 2012) and its remineralization at depth (Boyd and Ellwood, 2010). Biologically produced Fe-binding organic ligands are (i) related to alleviation of Fe stress [bacterially-produced siderophores (Rue and Bruland, 1995; Trick et al., 1995; Mawji et al., 2008; Velasquez et al., 2011), the toxin domoic acid produced by the diatom Nitzschia (Rue and Bruland, 2001; Maldonado et al., 2002)], (ii) retention of episodic iron input (Adly et al., 2015; Westrich et al., 2016), or (iii) ligands produced through biological recycling or basal biological activity such as hemes (Gledhill et al., 2013), ferritin (Castruita et al., 2008), polysaccharides (Ozturk et al., 2004; Hassler et al., 2011a), and EPS (Nichols et al., 2004; Hassler et al., 2011b; Norman et al., 2015). Interestingly, amongst most of these organic ligands, only EPS were reported to contribute to the pool of HS-like substances (Norman et al., 2015) which is not surprising given that EPS and HS are polyfunctional macromolecules.

Ligand loss terms could be associated with downward export fluxes mediated by biological production and chemical aggregation (Figure 1B). Export of organic carbon has been reported following large blooms (DiTullio et al., 2000), grazing activity (e.g., salps, Iversen et al., in review; Cabanes et al., in preparation) or along salinity gradients found in estuaries (Sholkovitz et al., 1978). It is currently unclear whether the transformation of organic compounds mediated by heterotrophic bacteria associated with the microbial carbon pump (e.g., accumulation of refractory DOM and remineralization) represents a loss or a production pathway for iron-binding organic ligands. The rapidly growing number of organic ligand measurements along with the basin-scale approach associated with GEOTRACES provide critical insights on the role of remineralization on the fate of ligands (e.g., Gerringa et al., 2015). Overall, remineralization is associated with a loss of organic ligands, since concentrations were found to decrease with depth and along the ocean circulation pathway, and furthermore a negative correlation was evident between ligands and apparent oxygen utilization in the NADW (Buck et al., 2015; Gerringa et al., 2015). Generally, the weaker ligands found at depth are thought to result from remineralization by heterotrophic bacteria (Hunter and Boyd, 2007; Boyd et al., 2010; Buck et al., 2015). The production of $\mathrm{L}_{2}$ as well as $\mathrm{L}_{1}$ ligands in remineralization experiments (Boyd et al., 2010; Bundy et al., 2016; Velasquez et al., 2016), clearly highlights a dynamic environment which is probably linked with bacterial colonization of sinking particles. Photochemistry is responsible for the production of weaker ligands and/or the degradation of iron binding ligands (e.g., Barbeau et al., 2001; Butler and Theisen, 2010; Gledhill and Buck, 2012), thus representing a loss pathway of strong ligands that can predominate in the upper few meters of surface waters (Figure 1) where they are likely to represent an important transient source of labile iron (Croot and Heller, 2012) to support phytoplankton growth.

\section{Humics}

The fluorescence properties of humics, identified by Parallel Factor Analysis (PARAFAC), have demonstrated that humiclike substances occur throughout the global ocean (Heller et al., 2013; Catala et al., 2016), accounting for 5-20\% of the DOC in deep and coastal waters (Harvey et al., 1983). Based on their 
specific signature (i.e., t-Peaks) riverine HS are found at depth in the North Atlantic and Pacific Oceans (up to 2000 and 5040 m, respectively; Medeiros et al., 2016). Based on their sources (riverine, run-off) high concentrations $(\mathrm{mg} / \mathrm{L})$ of the terrestrial HS is expected to occur in estuarine and coastal waters (Laglera and van den Berg, 2009; Krachler et al., 2015). An inverse ${ }^{228} \mathrm{Ra}$ modeling study (Kwon et al., 2014) has suggested that groundwater discharge is also an important source of HS whose signature is found throughout surface waters (i.e., $18 \mathrm{~m}$ depth) of the temperate Indian and North Atlantic Oceans. Other sources are sediments (Bordovsky, 1957), dust (Paris and Desboeufs, 2013, Figure 2A). To date, the characterization of organic ligands associated with hydrothermal vents, a terrestrial input, is in its infancy but will be highly relevant for upwelling regions (e.g., Sander and Koschinsky, 2011; Kleint et al., 2016); their potential contribution to any of the three groups of ligands considered is not yet known. In addition, rain contains humics but also malonic, citric, and oxalic acids that stabilize iron in solution (Willey et al., 2000) as well as iron binding ligands detected by electrochemistry (Cheize et al., 2012; Table 1).

It is now recognized that terrestrial DOC is exported to the ocean (Seidel et al., 2015), and is injected into oceanic deep waters via thermohaline circulation (Medeiros et al., 2016). At depth, HS is present at low concentrations but is stable ( $>24$ ky; Lechtenfeld et al., 2014). Such high stability probably reflects low susceptibility to bacterial breakdown and infrequent photodegradation occurring between ventilation cycles of deep water to the surface every $\sim 1000$ years (Primeau and Holzer, 2006). In the deep sea, the breakdown rate of this recalcitrant DOM is much slower and this pool reaches ${ }^{14} \mathrm{C}$ ages of 1000's of years (Jiao et al., 2010), which is consistent with the estimated 1000 year residence time of iron-binding organic ligands in the NADW (Gerringa et al., 2015). The distribution of fluorescent properties of dissolved organic matter, used as a proxy for humics (Coble, 2007), shows lower levels in surface waters, increasing at mid-depth, and becoming relatively constant in the deep waters (Yamashita et al., 2010; Heller et al., 2013; Catala et al., 2016). This distribution suggests that photo-degradation has the strongest impact on humics distribution whereas the processes of microbial degradation and particle adsorption are not reflected in the shape of vertical profiles. Knowledge of the iron-binding properties of HS and detection by ASV suggest that terrestrial HS makes up $\sim 18 \%$ of the DOC pool in coastal and $\sim 4 \%$ in deep ocean waters (Laglera and van den Berg, 2009; Bundy et al., 2014).

In open ocean surface waters, the fluorescence signature of humics appear to be best related to oxygen utilization and chlorophyll $a$ concentrations as a result of in-situ production (Stolpe et al., 2014), hence a biologically-mediated distribution has been proposed (Yamashita et al., 2010; Tanaka et al., 2014; Catala et al., 2016). In this case, the peak in ligand concentrations associated with higher stocks of phytoplankton and bacteria could be associated with HS-like produced by biological excretion. Marine bacteria rapidly produce such material from labile compounds (Ogawa et al., 2001; Stolpe et al., 2014), thus acting as an in-situ source of marine HS-like material. Refractory DOM, (part of which would be HS-like substances)
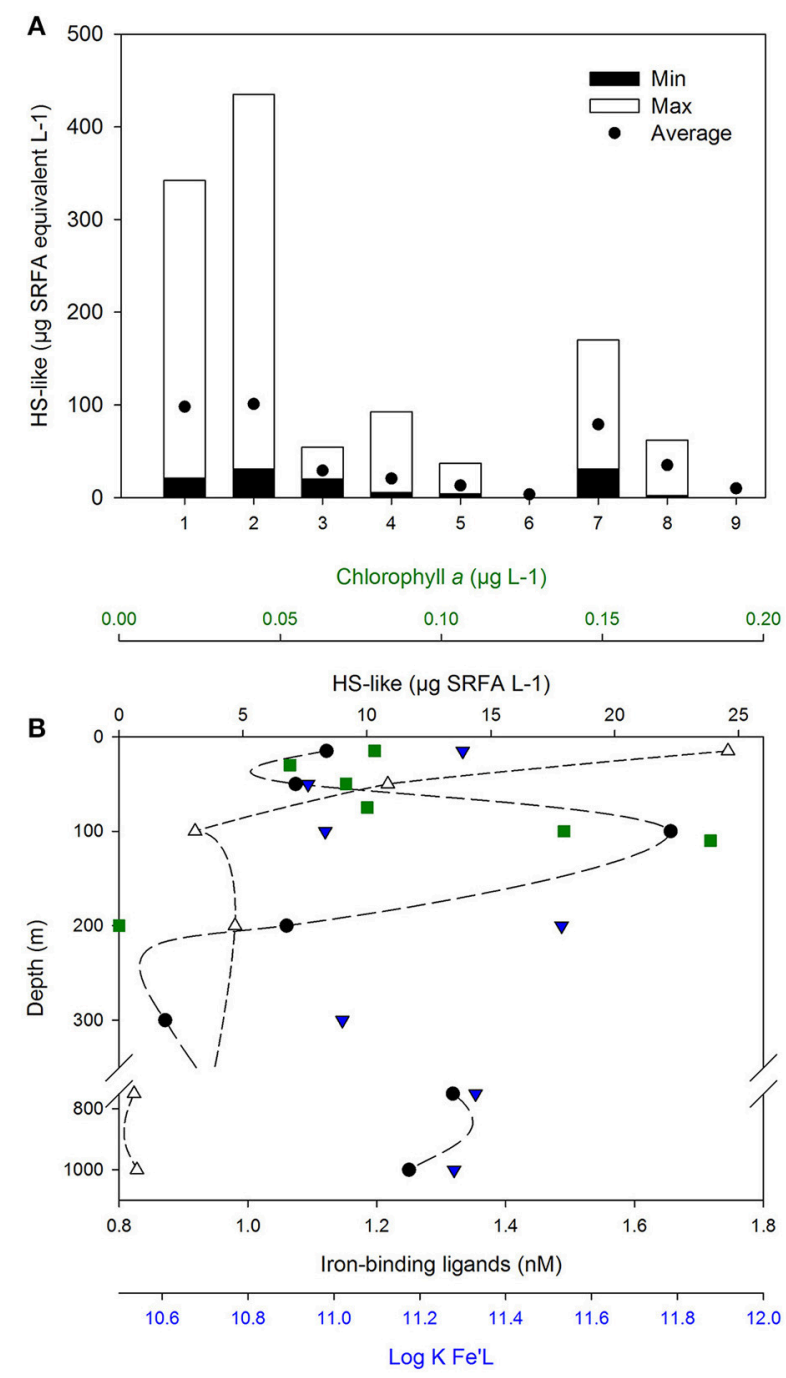

FIGURE 2 | Sources and distribution of HS-like. (A) HS-like reported across various marine environments (1), Coastal NSW, Australia ( $n=12$, Norman, 2014); (2), River plume, NSW, Australian ( $n=7$, Norman, 2014); (3), Irish Sea ( $n=3$, Laglera and van den Berg, 2009); (4), West Antarctic Peninsula ( $n=15$, Trimborn et al., 2015); (5), Pacific open Ocean $(n=6$, Hassler et al., 2011b; Norman et al., 2015); (6), Deep Pacific Ocean ( $n=1$, Laglera and van den Berg, 2009); (7), Sea-ice ( $n=6$, Schoemann et al. personal communicaton; Lannuzel et al., 2008) and sources of ligands; (8), EPS ( $n=4$, Norman et al., 2015); (9), Australian dust from the Buronga region $[n=1$, (Norman, 2014)]. Minimal, maximal, and average concentrations are shown, expressed in $\mu \mathrm{g} \mathrm{L}^{-1}$ Suwannee River Fulvic Acid (SRFA) Std 1 (IHSS) in seawater and in $\mu \mathrm{g}$ SRFA $\mathrm{mg}^{-1}$ EPS and dust. Measurements from Laglera and van den Berg (2009) were converted from SRHA to SRFA using a 10.75 conversion factor derived from calibration curves with each humic material (Hassler, unpublished data). Depth profile measured in the South Pacific Ocean (B; $32.3^{\circ} \mathrm{S}, 170.6^{\circ} \mathrm{W}$, June 1st 2011, GEOTRACES P06 line, Cabanes et al., in preparation) showing the concentrations of Chlorophyll a (green square), HS-like (empty circle), and iron-binding ligands (L, full circle) with their conditional stability constant ( $\log \mathrm{K}_{\mathrm{Fe}} \mathrm{L}$, blue triangle down).

is also produced in-situ in the oceans and coastal seas as part of the remineralization of phytoplankton-derived organic matter (Burkhardt et al., 2014). 
Humic signatures detected by electrochemistry (Laglera and van den Berg, 2009) were reported within HS, EPS and atmospheric dust, and are present in river plumes, coastal waters, sea-ice as well as in surface waters and at depth in the open ocean (Figure 2A; Laglera and van den Berg, 2009; Hassler et al., 2011b; Norman, 2014; Norman et al., 2015; Trimborn et al., 2015). This overlap in the detection of EPS, HS, and HS-like indicates a lack of resolution of the analytical techniques used (fluorescence, voltammetry) and therefore an inability to discriminate between the three compounds. Differences in fluorescent behavior of HS and HS-like substances (Heller et al., 2013; Stolpe et al., 2014) imply that there must be different reactivity, but identical responses to electrochemical detection suggests their speciationreactivity is indistinguishable (Laglera and van den Berg, 2009). More studies are thus required to characterize whether HSlike have a structural or chemical signature in relation to their sources in order to further differentiate them. However, the observation that coastal studies have found correlations between HS-like and $\mathrm{L}_{2}$ (Laglera and van den Berg, 2009; Abualhaija et al., 2015), but open ocean studies have variously found direct relationships between HS-like substances and $\mathrm{L}_{2}$ Abualhaija et al., in review, and no relationship between the distribution of HSlike substances and $\mathrm{L}_{2}$ (Cabanes et al., in preparation; Figure 2B) or Fe solubility (Heller et al., 2013), points toward regional differences in ligand distributions between coastal and open ocean.

\section{Siderophores}

Much of the corroborating evidence for the production of siderophores by bacteria and cyanobacteria came from early lab studies (e.g., Reid et al., 1993; Wilhelm and Trick, 1994) and measurements in the Atlantic and Southern Oceans (Mawji et al., 2008, 2011; Velasquez et al., 2011). The role of marine fungi which act in the decomposition and remineralization of organic matter is currently poorly documented. Many terrestrial fungi, including those in the rhizosphere, and marine fungi produce siderophores (Haselwandter, 1995; Baakza et al., 2004).

The molecular chemistry of siderophores is specifically designed to bind iron strongly (Vraspir and Butler, 2009) and these are expected to be amongst the strongest iron binding ligands. Enhanced production of siderophores should be linked to regional patterns in heterotrophic bacterial and cyanobacteria iron stress and its opportunistic alleviation (Kirchman et al., 2009; Adly et al., 2015; Westrich et al., 2016) using a wide range of iron acquisition strategies (Cordero et al., 2012; Moran et al., 2016). Most of the insights gained into siderophores distributions have relied upon the comparable conditional stability constants between them and the $\mathrm{L}_{1}$ class of ligands, even though no direct links have been made to date between siderophores and the $\mathrm{L}_{1}$ class (MacRellis et al., 2001). Time-series changes in $\mathrm{L}_{1}$ ligand concentrations and shifts in heterotrophic bacterial activity (i.e., a rapid up-regulation of siderophore receptor expression) following a purposeful mesoscale iron enrichment in the NE Pacific provides further strong indirect evidence of such a linkage (Adly et al., 2015). Siderophores are likely not restricted to surface waters as heterotrophic bacteria are found throughout the water column (but at much lower abundances than in the surface ocean; Boyd et al., 1999) and sinking particles are heavily colonized by bacteria (Ploug et al., 1999), some of which produce siderophores (Cordero et al., 2012; Figure 1B). Indeed, the production of siderophores and $\mathrm{L}_{1}$ ligands were recently measured during a subsurface ocean remineralization experiment (Bundy et al., 2016; Velasquez et al., 2016).

It is to be noted that the presence of siderophores is not solely reported in low dissolved iron regions (Mawji et al., 2008). A transcriptomics study of the response of the cyanobacteria Synechococcus PCC7002 showed that the genes involved in the siderophores/iron uptake pathways (siderophores and receptors) were induced at inorganic iron concentrations typical of coastal areas (Blanco-Ameijeiras and Hassler, 2015), likely due to high biological iron requirements for growth. Moreover, strong iron-binding ligands were only reported following high iron addition in a study using Alteromonas sp. (Hogle et al., 2016). It is therefore reasonable to expect siderophores, at low concentrations, across most of the ocean (see Mawji et al., 2008; Boiteau et al., 2016a). Detection of individual siderophores in seawater is in its infancy but the combination of high-performance liquid chromatography with inductivelycoupled plasma-mass spectrometry represents a promising method (Boiteau et al., 2013) which has recently been used to characterize the joint release/excretion of several siderophores in a Synechococcus lab culture (Boiteau and Repeta, 2015). Furthermore, low picomolar levels of individual siderophores, and lateral trends in their distribution were evident in both Californian waters and along the South Pacific GEOTRACES zonal section, suggesting distinct trends in the distribution of a range of siderophores (Boiteau et al., 2016a; Repeta et al., 2016). However, high concentrations of $\mathrm{L}_{1}\left(\sim 1 \mathrm{nmol} \mathrm{L}^{-1}\right)$ re often detected (e.g., Boyd and Tagliabue, 2015; Buck et al., 2015; Gerringa et al., 2015), clearly suggesting that not only siderophores contribute to this strong ligand pool.

Clearly, there must be loss terms for siderophores otherwise there would be a gradual build-up in their stocks. Photochemical breakdown of siderophores leading to the production of weaker ligands (Barbeau et al., 2001) or alteration of their complexing properties (Amin et al., 2009) is a leading candidate for siderophore loss in surface waters. However, there must be other highly influential loss processes such as grazing (surface and subsurface waters; Kraemer et al., 2006, 2015), as bacterial stocks are tightly controlled within the microbial food-web (which rapidly recycles iron; Strzepek et al., 2005). For example, the fate of siderophores within or on the surfaces of heterotrophic bacteria as they pass through the acidic $(\mathrm{pH}$ 3) micro zooplankton gut (Barbeau et al., 1996) is unknown. Viral lysis is also a major fate of heterotrophic bacteria (Boyd and Tagliabue, 2015), but again little is known about whether such processes alter the molecular chemistry of the siderophores. Finally, the fate of siderophores taken up by piracy strategy by other bacteria (Granger and Price, 1999; Cordero et al., 2012) is unclear, although the "public good" theory suggests an efficient recycling of siderophores.

\section{Exopolymeric Substances and Saccharides}

Interestingly, the most abundant components of dissolved organic matter are carbohydrates, with $\sim 50 \%$ present as polysaccharides (Benner et al., 1992), which could be an 
important component of the ligand soup. Vertical distributions of polysaccharides suggest that they are reactive in surface waters, rapidly consumed by microorganisms and part of the labile pool of DOC (Pakulski and Benner, 1994). As polysaccharides are a major constituent of EPS (see above), we thus assumed that EPS would follow a similar distributional pattern to that of polysaccharides (Figure 1A). The half-life of the EPS and polysaccharides is expected to be short (hours-years), their production rate high but their measured in-situ concentration is reported to be relatively "low" (e.g., nM EPS or $\mu \mathrm{M}$ carbon; Panagiotopoulos and Sempere, 2005; Norman et al., 2015). Indeed, neutral sugars within DOC have residence time shorter than 3 years (Repeta and Aluwihare, 2006). As for any short-lived reactive compounds, their importance might be under-estimated since they do not accumulate, but cycle, in the water column.

A large number of marine bacterio- and phyto-plankton release polysaccharides, either as EPS, or from intracellular storage products following cell lysis or grazing (e.g., Decho, 1990; Nichols et al., 2005, Figure 1B). Constituents of phytoplankton cells are expected to be present in surface waters, especially following the termination (i.e., cell senescence) and decline of phytoplankton blooms. Sources of actively excreted compounds such as EPS are mostly associated with biological activity in surface waters and sea-ice (Table 1). It is to be noted that Alteromonas sp., which synthesize strong iron binding ligands ( $\mathrm{L}_{1}$ typically assigned to siderophores, Hogle et al., 2016) also produce EPS able to strongly bind iron (Hassler et al., 2011a). Since EPS are produced for many functions (Decho, 1990; Hoagland et al., 1993; de Brouwer et al., 2005), they are likely to be present in relatively high concentrations (Hassler et al., 2011a; Norman et al., 2015). EPS are expected to be particularly abundant in waters characterized by high chlorophyll concentrations or on the base of sea-ice (Table $\mathbf{1}$ ). Carbohydrate exudation products tend to be linked to nutrient limitation and the stationary growth phase of cells (e.g., Myklestad, 1977; Liu et al., 2001), such as at the decline of a phytoplankton bloom when cells continue to fix carbon photosynthetically but have insufficient nutrients available for macromolecular synthesis (e.g., Boyd et al., 2005). To date, a clear link between phytoplankton Fe limitation and the specific production of exopolymeric substances is missing but putative proteomic evidence has been presented (Nunn et al., 2013). However, EPS release is not be restricted to surface waters; bacterial exopolymers were reported in the deep-ocean, including hydrothermal vents (e.g., Nichols et al., 2005), but their specific role(s) within Fe biogeochemistry remains unknown.

Saccharides and EPS iron-binding affinities usually assign them to the $\mathrm{L}_{2}-\mathrm{L}_{4}$ ligand classes (Hassler et al., 2011b). However, recent data showed that EPS could contribute to the $\mathrm{L}_{1}$ ligand pool (Norman et al., 2015), suggesting stronger binding stability constants for EPS (at the borderline of $\mathrm{L}_{1}-\mathrm{L}_{2}$ ) than for pure saccharides $\left(\mathrm{L}_{3}-\mathrm{L}_{4}\right)$. Despite the nature of EPS remains unknown leading to unsolved mechanism(s) for iron binding, they are rich in polysaccharides pointing toward a role for carboxylic groups (Janse et al., 1996; Nichols et al., 2005). All EPS tested so far contributed to the pool of HS-like substances that are electrochemically detected (Hassler et al., 2011b; Norman et al.,
2015; Figure 2A). This suggests that they are a major contributor to the marine HS-like pool associated with biological excretion and hence mostly present in surface waters. Data suggest that EPS from phytoplankton are smaller in size and make a greater contribution toward organic ligands and HS-like substances than bacterial EPS (Norman et al., 2015); but differences in culture growth media and the EPS analytical protocol between studies prevent a definitive conclusion at present.

Considering that EPS could represent up to $1 \%$ the total DOC pool, their production rate could be as high as for labile DOC (0.15-0.25 Pg C yr ${ }^{-1}$, Hansell, 2013; Norman et al., 2015). Based on the observation that $34 \%$ of bacterial EPS was carbon (Hassler et al., 2011a) and a median ligand contribution of $18 \mu \mathrm{mol} \mathrm{L}$ $\mathrm{g}^{-1}$ EPS (Hansell, 2013; Norman et al., 2015), the production rate of ligands from EPS of $2.4 \mathrm{nmol} \mathrm{d}^{-1} \mathrm{~L}^{-1}$, which is close to concentrations and production rates of ligands determined previously (Boyd et al., 2010; Gledhill and Buck, 2012; Völker and Tagliabue, 2015). This production rate suggests that EPS represent an important group of ligands accounting for most of iron binding ligands and $\sim 14 \%$ HS-like substances in the SubAntarctic seasonal bloom occurring between Australia and New Zealand (Norman et al., 2015).

\section{A Putative Role for Exopolymeric Substances in Size Distribution and Vertical Transfer of Iron-Binding Ligands}

EPS are considered to play a central role in the vertical flux of matter between the surface and the deep ocean. Their solubility and their ability to clump together or with other organic macromolecules and form biogels (or TEP: Transparent Exopolymer Particles) over time enables them to contribute to the pool of dissolved organic matter (DOM) but also to that of particulate organic matter ( $\mathrm{POM}$ ) when aggregated. In the geomicrobiology literature there is also growing recognition of the role that gel production plays in retaining metals (Melton et al., 2014). Whereas, TEP is often associated with marine snow and particulate carbon export, this idea was challenged by the observation that TEP could be positively buoyant (c.f. seawater) (Azetsu-Scott and Passow, 2004; LaurenceauCornec et al., 2015). Therefore, EPS and TEP can also be associated with ascending organic material, colloids, and also with microorganisms (Azetsu-Scott and Passow, 2004). Recent studies have suggested that polysaccharides, EPS as well as viruses could represent a significant pool of colloidal iron binding ligands (Benner, 2011; Hassler et al., 2011a; Bonnain et al., 2016). Indeed, iron associated with the tails of phages might mimic Fesiderophore complexes thus providing an efficient way to infect heterotrophic bacteria (Bonnain et al., 2016).

Because siderophores are small organic compounds (Butler and Theisen, 2010) able to solubilize colloidal $\mathrm{Fe}$ bearing minerals including oxyhydroxides (Kraemer et al., 2005), they are thus expected to be found in the soluble phase. However, soluble ligands show a lower conditional stability constant for iron binding than colloidal ligands (Boye et al., 2010), thus contradicting the hypothesis that siderophores are mainly present in the soluble phase. One possibility is that upon release the siderophores may become associated with organic colloids 
(Buck et al., 2007). Similarly, hemes (<1000 Da) were measured in association with marine particles, possibly a result of their low solubility in seawater (Gledhill and Buck, 2012). EPS could hence potentially trap other important organic ligands or $\mathrm{Fe}$ oxides within the colloidal fraction (Stolpe and Hassellov, 2010; Figure 1B) but also in either sinking or ascending particles (Azetsu-Scott and Passow, 2004). This capacity of EPS to adsorb organic ligands and iron oxides takes the challenge of chemically characterizing natural Fe-binding ligands in the field a step further. Capture of biological molecules (e.g., the enzyme Rubisco) within the gel phase was reported and proposed as a stabilizing mechanism, by which remineralization is weakened resulting in a significant increase in their residence time up to decades (Orellana and Hansell, 2012).

\section{IMPLICATIONS OF THE CO-EXISTENCE OF IRON-BINDING LIGANDS}

In the presence of multiple Fe binding ligands, competition will take place for iron. Because siderophores are present at low pM levels whereas dissolved iron occurs at high pM levels, they tend to be saturated with iron even in presence of much higher concentrations of competing ligands that bind iron less strongly (e.g., $\mathrm{L}_{2}$ ). This can be numerically verified using the following seawater composition based on relevant literature (Figure 3A): $0.1-1 \mathrm{nM}$ dissolved Fe, $1.1 \mathrm{nM}$ of ligands with a conditional $\log \mathrm{K}_{\mathrm{Fe}^{\prime} \mathrm{L}}^{\prime}=11.45$ and $10 \mathrm{pM}$ siderophores with $\log \mathrm{K}_{\mathrm{Fe}^{\prime} \mathrm{L}}^{\prime}=12.5$ (these constants are based on $\mathrm{Fe}^{\prime}$ ). The concentration and stability constant for $\mathrm{L}_{2}$ are the average values from a recent compilation of oceanic ligands (Caprara et al., 2016), whereas the siderophores concentration is representative of their concentrations in the ocean (e.g., Mawji et al., 2008, 2011; Repeta et al., 2016). The siderophore conditional stability constant was chosen to match that of desferrioxamine $\mathrm{B}$ a hydroxamate often use as a model siderophore (Maldonado et al., 2005; Hassler et al., 2013; Cabanes et al., in preparation). In spite of the relatively small difference in complex stability (10fold) between the ligands species and the much more (100-fold) abundant background $\mathrm{L}_{2}$ ligands, the $10 \mathrm{pM}$ of siderophore is largely complexed with iron but, $\geq 98 \%$ of the iron is associated with the $\mathrm{L}_{2}$ ligands (Figure $\mathbf{3 A}$ ). These calculations are based on the assumption of a steady-state of siderophore production, combined with a near-equilibrium in the complexation reactions, a scenario that most likely fails to reflect conditions in natural waters due to slow reaction kinetics (Hering and Morel, 1989).

It is anticipated that the concentration of siderophores is higher (perhaps tenfold) in the diffusion boundary layer of the bacterium producing them (Volker and Wolf-Gladrow, 1999) or in the surrounding particles colonized by heterotrophic bacteria (Cordero et al., 2012). In these specific locations, the amount of iron bound with siderophores could be proportionally greater than for the bulk seawater medium. Alternatively, there may be kinetic implications as the residence time within the diffusion layer is short (e.g., <0.1 s) for hydrophilic siderophores (Volker and Wolf-Gladrow, 1999) but could be longer for those equipped with a hydrophobic (lipophilic) tail. The kinetics of

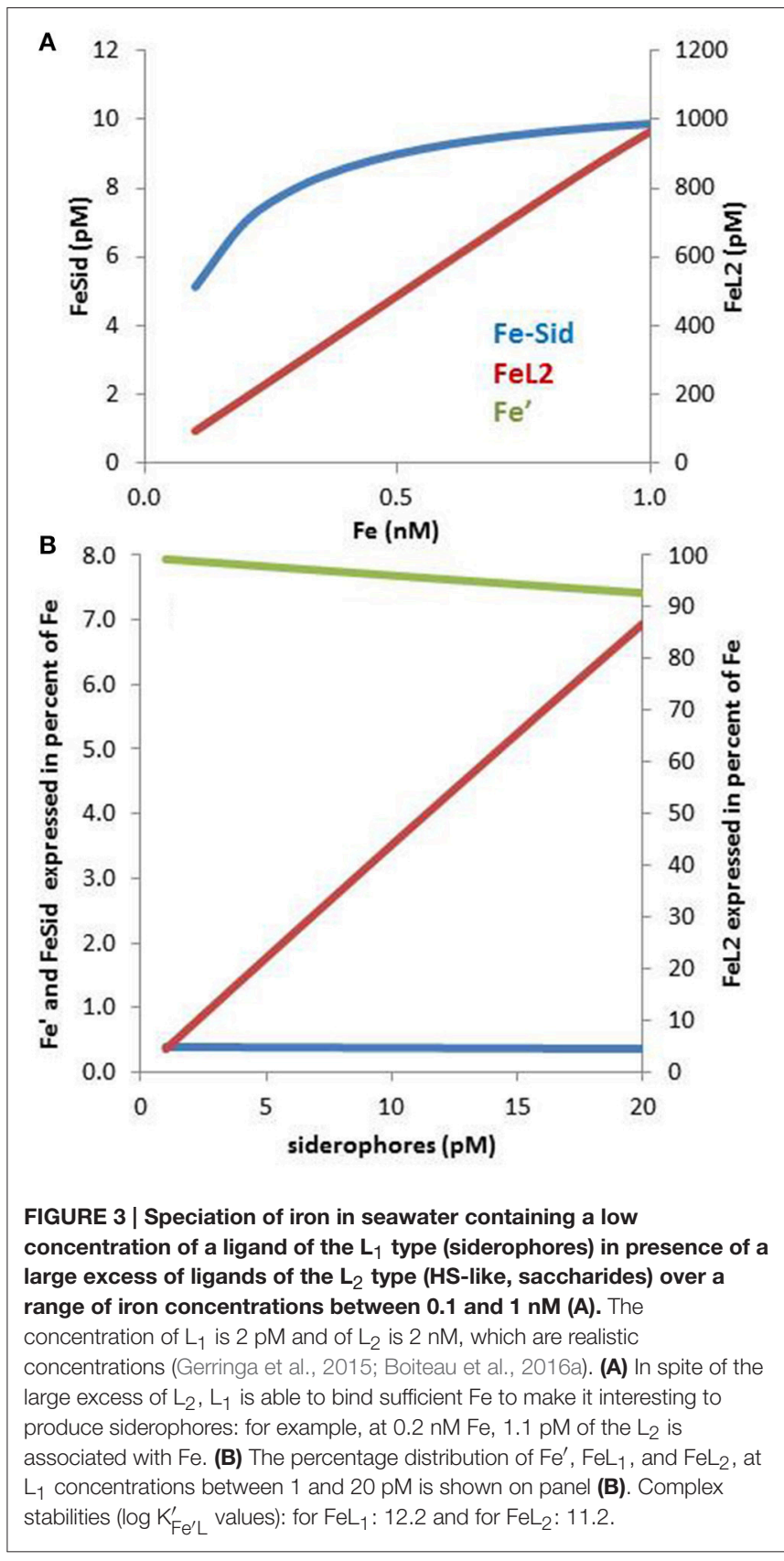

iron speciation between a recently released siderophore and iron (already complexed with background $\mathrm{L}_{2}$ ligands in seawater) is probably controlled by the dissociation rate of organically bound iron, with a half-life of minutes [e.g., 9 min determined for $\mathrm{Fe}$ (III) bound with ligands in seawater; Abualhaija and van den Berg, 2014], which can been seen as relatively slow compared to phytoplankton Fe biological uptake rate (Hudson and Morel, 1990).

Only a few $\%$ of the $\mathrm{FeL}_{2}$ species needs to dissociate to effectively saturate the siderophores in our numerical example. The observations of low concentrations $(<10 \mathrm{pM})$ of siderophores (Boiteau et al., 2016a; Repeta et al., 2016) may be 
due to energetic constraints associated with their production (Volker and Wolf-Gladrow, 1999) and the "public goods" theory, in which synergies and multiple uptake strategies take place amongst a consortium of heterotrophic bacteria (e.g., Cordero et al., 2012). The cost of siderophores production must be traded off against the benefit obtained from the ability to rapidly sequester iron that is supplied episodically such as by dust inputs (Boyd and Tagliabue, 2015; Westrich et al., 2016). Overall, these calculations (Figure 3A) point out that even a low concentration of siderophores is effective for bacterial uptake as they can use the bulk of Fe- $\mathrm{L}_{2}$ complexes as a suitable exchangeable iron pool. On the other hand, the $\mathrm{Fe}-\mathrm{L}_{2}$ pool, representing more than $98 \%$ of the dissolved iron, is directly relevant for the overall iron solubility and residence time in surface water (Johnson et al., 1997). Moreover, if $\mathrm{FeL}_{2}$ is highly bioavailable to phytoplankton, as suggested for EPS (Hassler et al., 2011b, 2014), this pool could potentially benefit phytoplankton growth (e.g., Hassler et al., 2011b). In this case, weak ligands would be important for iron phytoplankton nutrition, as reported for other metals such as $\mathrm{Zn}$ (Aristilde et al., 2012) and $\mathrm{Cu}$ (Walsh et al., 2015).

The relative contribution of ligands depends also on the "exchangeable" iron pool. This exchangeable pool is often referred to as the dissolved iron pool (Gledhill and Buck, 2012), a possibly misleading assumption as not all the dissolved iron might be exchangeable and as particulate iron can also react with organic ligands such as siderophores and HS (Kraemer et al., 2005; Paris and Desboeufs, 2013; Fishwick et al., 2014). It is also to be noted that the co-existence of multiple metals has implications for iron biogeochemistry as organic ligands may bind metals with different binding affinities, potentially leading to competition, representing a research direction mostly unexplored for in-situ oceanic ligands.

The conditional stability constant of desferrioxamine-B (DFB; Cheize et al., 2012; Abualhaija and van den Berg, 2014) in rain- and seawater is more than 5 orders of magnitude greater than that for other trace metals in simple electrolyte solutions [e.g., $\mathrm{Al}(\mathrm{III}), \mathrm{Cu}(\mathrm{II}), \mathrm{Zn}(\mathrm{II})$; Hernlem et al., 1996], suggesting that other metals cannot compete with binding of iron using similar siderophores. Copper and zinc complexation with HStype ligands in seawater is strong (Yang and van den Berg, 2009), and copper and iron compete for $\mathrm{L}_{2}$ type ligands in estuarine and coastal waters (Abualhaija et al., 2015). The conditional stability constants for marine organic ligands with nickel and cobalt are high (Martino et al., 2004; Ellwood et al., 2005; Bown et al., 2012; Baars and Croot, 2015) suggesting a possible competition with iron providing they bind with the same ligands. Indeed, $\mathrm{Cu}$ and $\mathrm{Ni}$ competition for binding to the same organic ligand has been recently observed (Boiteau et al., 2016b; this issue).

\section{TOWARD A MAP OF IRON-BINDING LIGAND DISTRIBUTIONS}

Several thousand organic compounds co-exist in seawater (e.g., Hertkorn et al., 2006). It is therefore unsurprising that numerous ligands are suspected to contribute to the overall electrochemical signature associated with $\mathrm{L}_{1}-\mathrm{L}_{4}$ (Table 1 ). The zonation of the key sources, production and loss pathways for Fe-binding organic ligands (Table 1, Figure 1B) enables an initial geographical delineation of regions to be drawn, where different ligands might be expected to dominate the bulk ligand pool. Differences in the types of organic ligands (HS, EPS, and siderophores) can indeed be mapped onto oceanic regions from coastal to offshore (Figure 4). HS and EPS are expected to decrease with distance from the coast but EPS remain at a comparatively high baseline; siderophores are present at low concentrations and expected to increase with distance from the coast (see below).Such distribution can be refined to get an overview of their geographical distribution at a basin-scale. Key factors that will determine broad-scale ligand distributions include: location of major oceanographic features (such as High Nitrate Low Chlorophyll waters) or regions of high productivity and/or downward export flux; geographical location of land masses, and major rivers; the longevity of each ligand class (Table 2) and how this intersects with timescales of oceanic circulation to distribute ligands in the oceans' interior. Smaller-scale regional characteristics, such as sea-ice dynamics, regions of dust supply, and phytoplankton seasonal bloom will be overlaid onto these broad-scale properties.

There is insufficient data for us to provide a robust quantitative estimate of the relative contribution of HS, EPS, and siderophores from the literature. We explore the implication of the co-existence of these three groups of ligands considering boundary conditions of their abundance in coastal, shelf, highly productive areas as well as open ocean (Figure 5). Using literature data and modeling projections, we have come up with preliminary estimates of the contribution of these ligand groups to the total ligand pool and iron chemistry (see Supplementary Material and Table S1 for details of the model parameterization). These projections enable us to provide the first estimates of the implication of the co-occurrence of these groups of

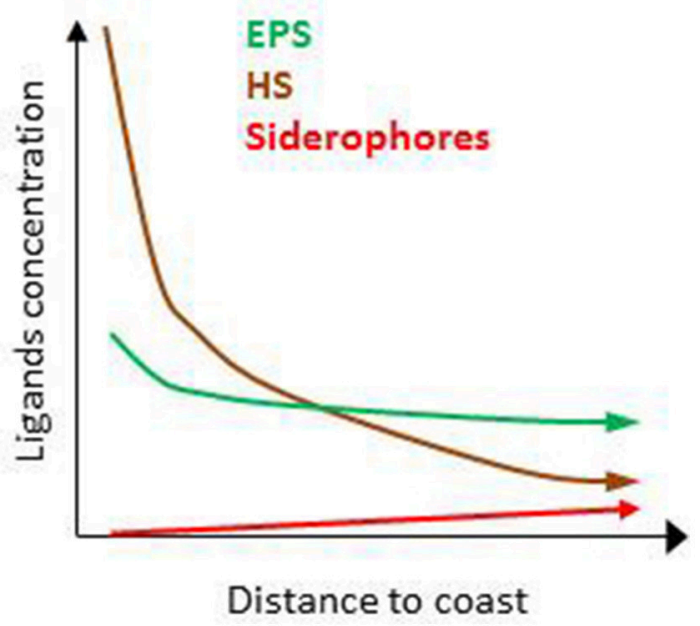

FIGURE 4 | Predicted distribution of humic substances (HS), exopolymeric substances (EPS), and siderophores relative concentrations with distance from the coast suggesting differences between coastal, offshore, and open ocean. 
TABLE 2 | Expected regional and seasonal distribution of the different organic ligands in relation to their external and in-situ sources and production pathways.

\begin{tabular}{|c|c|c|c|c|c|c|}
\hline \multirow[t]{2}{*}{ Ligands sources } & \multicolumn{2}{|c|}{ Low Chl a } & \multicolumn{3}{|c|}{ High Chl a } & \multirow[t]{2}{*}{ Seasonality } \\
\hline & Fe-limited & Nutrient-limited & Coastal & Upwelling & Bloom & \\
\hline \multicolumn{7}{|l|}{ EXTERNAL } \\
\hline Coastal & & & ++ & ++ & & SU \\
\hline Atmospheric & + & ++ & + & & & \\
\hline dry & & & & & & SU \\
\hline wet & & & & & & SP-SU \\
\hline Sea-ice & + & - & + & & & SP-SU \\
\hline Hydrothermal & + & & & ++ & & \\
\hline \multicolumn{7}{|l|}{ IN-SITU } \\
\hline Photochemical & ++ & ++ & + & + & + & SU \\
\hline Biological & & & & & & SP-SU \\
\hline Fe-stress & ++ & - & \pm & \pm & \pm & \\
\hline Basal activity & + & + & ++ & ++ & ++ & \\
\hline Recycling & ++ & ++ & + & + & + & \\
\hline Remineralization & + & + & ++ & ++ & ++ & \\
\hline
\end{tabular}

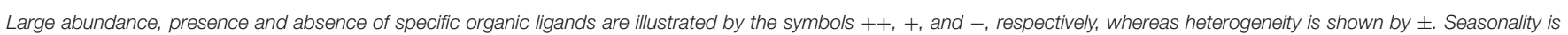
associated with the season at which each sources is the most pronounced [spring (SP) and summer (SU)].

organic ligands in regions where specific ligands are expected to dominate.

\section{Broad Zonation of Ligand Distributions Geographical Zonation of Organic Ligands}

The terrestrial provenance of HS points to them being the dominant ligand type in coastal regions (Figure 4), with HS concentration decreasing with distance to the coast (due to dilution and mixing). Indeed, in our modeling projection, HS dominate the ligands pool in coastal water, representing up to $90 \%$ of the three groups of ligands considered here. With $85-90 \%$ of Fe bound to HS, HS dominate Fe biogeochemistry, hence representing an important group of $\mathrm{L}_{2}$ ligands in coastal waters (Figure 5A). As we move out of the coast, HS decreases up to one order of magnitude in open ocean water, and there do not dominate Fe biogeochemistry (Figure 5D). Geographical land mass distributions and freshwater run-off patterns are thus key factors for the distribution of HS throughout the ocean. HS are expected to be a class of Fe-binding ligand that is present in significant amount both in surface coastal waters representing up to $18 \%$ of the DOC and ligands (Laglera and van den Berg, 2009; Bundy et al., 2014). Hence, HS will likely dominate the ligand pool in the Arctic which is close to riverine and sedimentary inputs. The Arctic is indeed a major source of DOC to the Atlantic Ocean (Benner et al., 2005). Terrestrial HS signatures based on ${ }^{228} \mathrm{Ra}$ were also found for most of the Equatorial to temperate Indian Ocean (Kwon et al., 2014), where HS are expected to be significant contributors to the overall ligand pool. However, due to limited land mass, lower ${ }^{228} \mathrm{Ra}$ signatures (Kwon et al., 2014) and thus lower input of HS is expected in the South Pacific and the Southern Ocean revealing large geographical demarcations between North and South hemispheres.
Oceanographic regionalization of organic ligands is also associated with the distribution of nutrients and chlorophyll $a$ (Chl $a$ as a proxy of biomass). In areas rich in nutrients and Chl $a$, usually observed in coastal, shelf and upwelling regions, organic ligands related to biological basal activity (EPS, saccharides, HSlike from excretion) could be a significant contributor to the group of organic ligands (see references herein, Figure 4). EPS can contribute to a significant amount of DOC, from $\sim 1 \%$ up to $50 \%$ of DOC in extreme bloom situations (Orellana et al., 2003) and EPS could thus dominate the organic ligands pool in phytoplankton blooms. Given that more than 1000 cells $/ \mathrm{mL}$ are reported across areas associated with low Chl $a$ (e.g., gyres, northern Tasman Sea; Hassler et al., 2014), EPS are expected to be associated with a significant baseline signature in $\mathrm{L}_{2}$ ligands (Figure 4). In our numerical exercise, the decrease of HS from coastal to the shelf waters, makes that HS and EPS are equally contributing to the $\mathrm{L}_{2}$ ligands pool, hence resulting in a complex situation where both EPS and HS contribute to $\mathrm{FeL}_{2}$ complexes (Figure 5B).In productive regions, EPS could represent up to $80 \%$ of the ligands, resulting in $88-89 \%$ of the iron being bound to EPS, Fe biogeochemistry in these regions are thus dominated by EPS (Figure 5C).

In the open ocean, the distinction between $\mathrm{Fe}$ and macronutrient limitation (Table 2) differentiates between High Nutrient Low Chlorophyll (HNLC) and Low Nutrient Low Chlorophyll (LNLC) surface waters, respectively (Moore et al., 2013). Iron is an important primary or secondary limiting nutrient in most of these waters, which together represent more than 30\% of the ocean (Boyd and Ellwood, 2010). In these regions, ligands excreted specifically in response to $\mathrm{Fe}$ stress such as siderophores are expected to be more abundant. Therefore, as recently observed in South Pacific waters (Boiteau et al., 2016a; Repeta et al., 2016), siderophore production is 


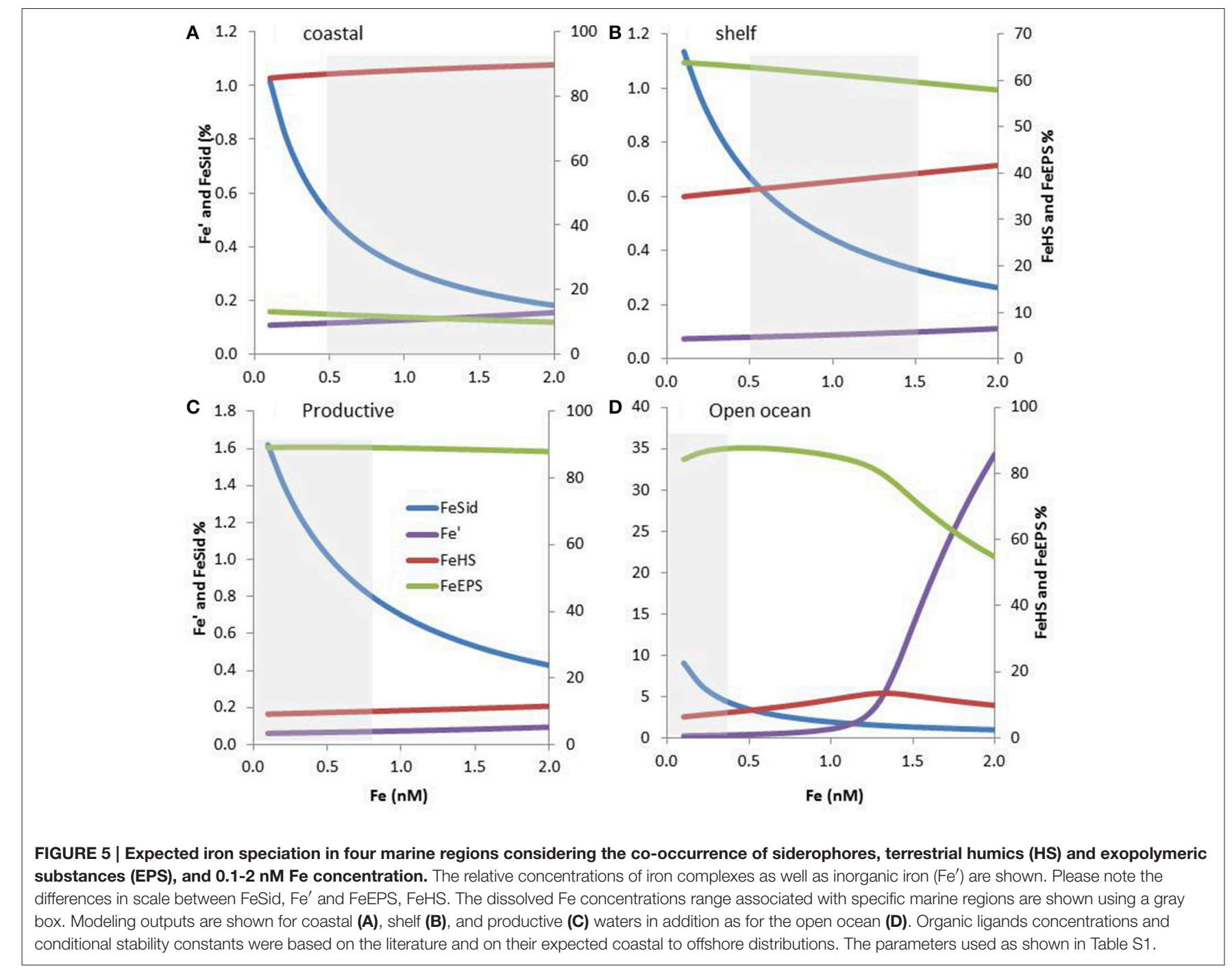

expected to increase from inshore (Fe-replete) to offshore (often Fe-limited; Figure 4). Because siderophores are reported at low levels (pM; Mawji et al., 2008, 2011; Boiteau et al., 2016b) they never dominate the total organic ligand pool. However, in all numerical projections (Figures 3, 5), siderophores are saturated with iron, making them efficient for bacterial nutrition (see Section Implications of the Co-Existence of Iron-Binding Ligands). Because of EPS is present in significant amount in open ocean waters, they tend to dominate the $\mathrm{L}_{2}$ ligand pool (Figure 5D).

Differences in organic ligand (HS-like) recycling in surface waters as well as remineralization at depth are expected between high and low Chl $a$ regions, providing a geographical basis to identify differences between recycled and remineralized ligands. In oligotrophic regions, comprising most of the open ocean and high latitude regions (Moore et al., 2013), recycling of organic compounds, and nutrients is expected to be efficient despite the low biomass. Indeed, in HNLC regions such as the remote Southern Ocean, Fe recycling is efficient, providing up to $90 \%$ of the Fe required to sustain phytoplankton growth (Hutchins et al., 1993; Strzepek et al., 2005; Sarthou et al., 2008; Poorvin et al., 2011). Alternatively, in high Chl a regions, which are mainly nutrient-replete, production rates of organic matter is high but recycling rates for organic matter and nutrients are often lower. The remineralization rates for DOC exported at depth from Hansell et al. (2012) provide an interesting framework to further reflect on potential global distribution of HS-like ligands associated with remineralization. Indeed, maximal remineralization rates were determined in the subtropical gyres and in the regions of deep-water formation in the North Hemisphere. On the other hand, in productive areas such as upwelling regions and in the Southern Ocean, remineralization rates were minimal.

Recent basin-scale studies in the Atlantic revealed a largescale pattern for organic ligand concentrations and conditional stability constants (Buck et al., 2015; Gerringa et al., 2015) with greater concentrations of organic ligands at high latitudes. Weaker stability constants were reported in the Arctic whereas 
the strongest ligands were reported in the Southern Ocean (Gerringa et al., 2015). The weaker conditional stability constants in the North could be attributed to large input of HS from the coast, contributing to $\mathrm{L}_{2}$ and $\mathrm{L}_{3}$ ligand classes, whereas in the South, strong ligands are likely due to widespread $\mathrm{Fe}$ limitation (siderophores) which prevail in the pelagic regions of the Southern Ocean (Tables 1, 2; e.g., Ibisanmi et al., 2011). From our zonation, differences in organic ligands at depth would also be expected from North to South with a dominance of HS and recently formed HS-like from sedimentary input and remineralization in the North, and HS-like from hydrothermal vents in the South. However, as stated earlier, we currently lack information about the specific chemical and structural signature of these organic compounds to refine their predicted zonation.

\section{Vertical Zonation}

Siderophore and EPS could contribute to the L1 ligands detected in surface water, however the discrepancy between siderophore $(\mathrm{pM})$ and $\mathrm{L}_{1}$ concentrations $(\mathrm{nM})$ suggest an important missing term, which is also the case for deep water (Figure 1A; Buck et al., 2015). Whether this discrepancy results from an analytical limitation to detect siderophores and/or whether other types of ligands are contributing remains unclear. In surface water, major constituents of the $\mathrm{L}_{2}$ class are jointly attributed to external input (coastal, dust, rain, hydrothermal vents, and sea-ice) and biological activity related to (i) basal activity, (ii) iron limitation, and (iii) recycling (Table 1). The relative importance of the ligands constituting the $\mathrm{L}_{1}-\mathrm{L}_{4}$ pool clearly depends on location, season and regional characteristics (Table 2); but HS, augmented by in-situ produced HS-like, are expected to contribute to an important baseline of Fe binding ligands. Three major impasses lie ahead to further constrain the relative contribution of $\mathrm{L}_{1}$ and $\mathrm{L}_{2}-\mathrm{L}_{4}$ ligands in surface waters: (i) a better delineation of basinscale and seasonal distribution of $\mathrm{L}_{1}$ ligands in surface waters, (ii) kinetic experiments needed for probing production rate and residence time of the different in-situ ligands, (iii) multiple analytical detection of ligands to better constrain the distribution, nature, and sources of strong but also weak ligands.

Ligand longevity or turnover is important to define in which depth strata specific ligands are observed (Figure 5A). Shortlived ligands are likely to be detected close to their sources of production and will not accumulate at depth. Given that siderophore concentrations do not increase with depth, they could be associated with short-lived compounds. However, at present, we cannot comment further on siderophore longevity as we know little on their loss terms and recycling rate, and their detection throughout the water column is limited due to their small concentration. Saccharides and EPS are expected to dominate in surface waters as extremely short-live compounds with residence time of the order of hours. However, processes at depth associated with EPS aggregation, export, buoyant particles, and whether EPS remineralization results in HS-like substance could significantly affect such a view (see references herein). Long-lived compounds such as HS with a longevity exceeding the global overturning circulation will accumulate in deep waters (see reference herein).
In addition to longevity, remineralization is an important determinant of the distribution of organic ligands at depth (Figure 1B). Given that HS is part of the pool of recalcitrant DOC, their contribution to remineralization is expected to be minor as compared to HS-like (see references herein). Due to residence time $>1$ year and their presence within microgel, saccharides, EPS, and proteins are also expected in this subsurface pool (Repeta and Aluwihare, 2006; Orellana and Hansell, 2012). As stated earlier, siderophores are expected to occur but at extremely low concentrations, unlikely to be detected by complexometric titrations. We currently lack functional and structural delineation amongst HS, and the numerous sources of HS-like material, to further differentiate amongst these organic ligands. For example, due to the many sources of HS-like ligands and their limited characterization, it remains unclear whether EPS could be a good proxy for HS-like from biological activity, recycling and remineralization. Below $1000 \mathrm{~m}$ depth, both DOC and Fe-binding ligands decrease along the global circulation path across ocean basins (Gledhill and Buck, 2012; Hansell et al., 2012; Gerringa et al., 2015). This suggests that long-lived refractory Febinding ligands, such as HS and HS-like substances (as measured by chemical, functional, and structural studies; Laglera et al., 2007; Catala et al., 2015; Medeiros et al., 2016) are present in deep water in all ocean basins. In this case both HS and HS-like from remineralization, terrestrial inputs and possibly hydrothermal vents could be important contributors of the ligand soup at depth. In the deep ocean, the composition if the ligands soup is expected to be quite homogeneous and stable as compared to the surface waters.

\section{Regional Geographical Zonation of Organic Ligands}

Regional variation in organic ligands is expected in relation to specific distribution of their sources and seasonality that can in time be overlaid onto the broad zonation presented above (Figure 4). In large river plumes (such as the Amazon and Mississippi Rivers; e.g., Powell and Wilson-Finelli, 2003), HS would be expected to dominate the pool of organic ligands (Figure 5A). Moreover, the relative contribution of HS, from rivers, coast and upwelling regions, to the ligand "soup" is predicted to be seasonally influenced with changing strength in precipitation as well as variability in the intensity of boundary currents and upwelling (Bakun and Nelson, 1991).

Atmospheric dry and wet deposition can also carry significant amount of iron-binding organic ligands (Cheize et al., 2012; Paris and Desboeufs, 2013; Table 1). Based on patterns of global desert dust deposition into the ocean, organic ligands originating from atmospheric sources might be important in the subarctic Western Pacific, North and equatorial Atlantic (including the West African upwelling region), and North and equatorial Indian Oceans, as well as in the Mediterranean and Tasman Seas (Price and Morel, 1998; Jickells et al., 2005; Mahowald et al., 2005; Cropp et al., 2013; Guieu et al., 2014). Dust deposition is highly seasonal, peaking often in summer but overlaid with strong episodic deposition (e.g., Price and Morel, 1998; Jickells et al., 2005; Cropp et al., 2013). The extent of wet deposition of organic 
ligands would be dependent on precipitation. For example, based on NASA's Tropical Rainfall Measuring Mission satellite (https://pmm.nasa.gov/trmm), precipitation has a consistent seasonality-for example heavy rain moves along the Equator in a seasonal pattern. Moreover, a significant amount of organic ligands is expected to be deposited at the time of monsoon (April-September) in the equatorial to temperate Indian and Pacific Oceans. Seasonal and geographical patterns of iron concentrations in rain suggests similar pattern in organic ligands with greater concentrations measured in spring and summer, as well as close to the coast (Willey et al., 2000). It is to be noted that the variability in the contribution and content of organic ligands associated with dry and wet deposition from differing sources (e.g., volcanic, desert, biomass burning, and anthropogenic) is mostly undocumented yet.

Sea-ice and icebergs can also be a significant source of organic ligands, but their influence is relevant only at high latitudes, in open ocean waters which are mostly iron-limited (Moore et al., 2013), but also close to the coast of Antarctica and the land masses associated with the Arctic region. At the time of Antarctic sea-ice melt, as the brine channels open, an important and rapid release of dissolved iron and organic ligands was observed (Lannuzel et al., 2007, 2015), suggesting a strong seasonal input (Table 2).

HS-like ligands from subsurface remineralization (Boyd et al., 2010; Heller et al., 2013; Medeiros et al., 2016) are expected to dominate in upwelling regions that are not under the major influence from hydrothermal inputs (e.g., Equator, Arabian Sea, Brazil Current, Peru, and Californian upwelling regions). Recently, studies have shown that hydrothermal vents can carry organic ligands and contribute to upwelled sources with significant $(>10 \%)$ impact on downward particulate carbon export for most of the Southern Ocean below the Polar Front, north of New Zealand and south of $40^{\circ} \mathrm{S}$ in the Pacific Ocean (Resing et al., 2015), resulting in potential geographical differences amongst upwelled ligands. A better characterization of organic ligands from hydrothermal vents and their susceptibility to bacterial transformation would thus provide invaluable details for these areas.

Phytoplankton seasonal blooms usually occur in spring and autumn, episodes that will likely affect the composition of organic ligands. In bloom situations, biologically-produced ligands related to metabolic basal activity (e.g., EPS, saccharides; Orellana and Hansell, 2012) are likely to be dominant (Figure 5C). Indeed, under bloom situation the EPS from Phaeocystis could represent up to $50 \%$ of the in-situ DOC (Orellana et al., 2003). It is expected that, as the bloom evolves, either nutrient limitation will develop, resulting in the production of specific ligands (e.g., DA, siderophores), or grazing events will terminate the bloom resulting in the release of degradation products. Finally, frontal zones between major currents are usually associated with high Chl $a$ variability compared to the surrounding waters (Belkin et al., 2009). Frontal regions are also reported to be important source regions for marine proteins such as Rubisco (Orellana and Hansell, 2012), suggesting that biologically-produced organic ligands might be important in frontal regions, a hypothesis that could be readily tested as part of future GEOTRACES voyages that cross such transition zones.

\section{OUTLOOK}

Our understanding of organic ligands is currently too limited to draw a detailed map of their relative distribution, however, we have demonstrated that differences in the contribution of a range of organic ligands to the bulk ligand pool can be expected across oceanic regions from coastal to offshore and from surface to deep waters. These broad trends can be built upon by superimposing regional inputs, seasonal trends, and patterns in biomass and nutrient limitation (Table 2 ) onto them. In addition to these spatial patterns, a strong seasonality is expected for different ligand types, with greater organic ligand input from coastal, sea-ice, atmospheric, and biological sources in springsummer whereas more HS-like ligands from remineralization are expected to reach surface waters in winter as vertical density gradients decrease. This combination of spatial and temporal gradients in different ligands supports our contention that a holistic viewpoint of the multi-faceted controls on ligands dynamics leading to a regional classification is essential to begin to understand why some ligands dominate in particular oceanic regions, depth strata, or exhibit seasonality and/or lateral gradients.

We advocate a number of approaches that will help to assign where this wide range of molecules fit across the spectrum of ligands that comprise the bulk ligand pool. For example, in order to track specific ligands and assess their distribution and residence time within the ocean, basin-scale studies simultaneously employing different techniques (such as liquid chromatography, mass spectroscopy, and electrochemistry) able to capture the diversity in composition and functions of organic ligands need to be complemented with isotopic and process studies testing specific analytical signatures related to sources. Such a trans-disciplinary approach will enable progress in resolving the nature of HS-like, as well as identifying what other components make up the rest of the strong $\mathrm{L}_{1}$ ligand. Because many type of organic ligands and trace element cooccur in seawater their ability to compete need to be further investigated. Further work using the distribution of ligands sources as well as a combination of proxies for key processes is required to take this regional approach further and provide a global picture of the distribution of the significant iron-binding organic ligands. Additionally, processes studies are required to refine biological sources and turn-over rates of organic ligands. The regional classification of ligands proposed here should however, help to interpret datasets from on-going global surveys, design future experiments, and improve biogeochemical models.

\section{AUTHOR CONTRIBUTIONS}

All authors listed, have made substantial, direct and intellectual contribution to the work, and approved it for publication. 


\section{FUNDING}

CH was funded by a SNF Professor Fellowship (PP00P2_138955). $\mathrm{PB}$ received support from an Australian Research Council Australian Laureate Fellowship project FL160100131 and Discovery Project DP130100679. Cv acknowledges general support from the University of Liverpool.

\section{ACKNOWLEDGMENTS}

Authors would like to thanks Dr. Louiza Norman, Mr. Damien Cabanes, and Ms. Sonia Blanco-Almeijeiras for their

\section{REFERENCES}

Abualhaija, M. M., and van den Berg, C. M. G. (2014). Chemical speciation of iron in seawater using catalytic cathodic stripping voltammetry with ligand competition against salicylaldoxime. Mar. Chem. 164, 60-74. doi: 10.1016/j.marchem.2014.06.005

Abualhaija, M. M., Whitby, H., and van den Berg, C. M. G. (2015). Competition between copper and iron for humic ligands in estuarine waters. Mar. Chem. 172, 46-56. doi: 10.1016/j.marchem.2015.03.010

Adly, C. L., Tremblay, J. E., Powell, R. T., Armstrong, E., Peers, G., and Price, N. M. (2015). Response of heterotrophic bacteria in a mesoscale iron enrichment in the northeast subarctic Pacific Ocean. Limnol. Oceanogr. 60, 136-148. doi: 10.1002/lno.10013

Amin, S. A., Green, D. H., Kupper, F. C., and Carrano, C. J. (2009). Vibrioferrin, an unusual marine siderophore: iron binding, photochemistry, and biological implications. Inorg. Chem. 48, 11451-11458. doi: 10.1021/ic9016883

Aristilde, L., Xu, Y., and Morel, F. M. M. (2012). Weak organic ligands enhance zinc uptake in marine phytoplankton. Environ. Sci. Technol. 46, 5438-5445. doi: 10.1021/es300335u

Azam, F., and Malfatti, F. (2007). Microbial structuring of marine ecosystems. Nat. Rev. Microbiol. 5, 782-791. doi: 10.1038/nrmicro1747

Azetsu-Scott, K., and Passow, U. (2004). Ascending marine particles: significance of transparent exopolymer particles (TEP) in the upper ocean. Limnol. Oceanogr. 49, 741-748. doi: 10.4319/lo.2004.49.3.0741

Baakza, A., Vala, A. K., Dave, B. P., and Dube, H. C. (2004). A comparative study of siderophore production by fungi from marine and terrestrial habitats. J. Exp. Mar. Biol. Ecol. 311, 1-9. doi: 10.1016/j.jembe.2003.12.028

Baars, O., and Croot, P. L. (2015). Dissolved cobalt speciation and reactivity in the eastern tropical North Atlantic. Mar. Chem. 173, 310-319. doi: 10.1016/j.marchem.2014.10.006

Bakun, A., and Nelson, C. S. (1991). The seasonal cycle of wind-stress curl in the subtropical easter boundary current regions. J. Phys. Oceanogr. 21, 1815-1834. doi: 10.1175/1520-0485(1991)021<1815:TSCOWS >2.0.CO;2

Barbeau, K., Moffett, J. W., Caron, D. A., Croot, P. L., and Erdner, D. L. (1996). Role of protozoan grazing in relieving iron limitation of phytoplankton. Nature 380, 61-64. doi: 10.1038/380061a0

Barbeau, K., Rue, E. L., Bruland, K. W., and Butler, A. (2001). Photochemical cycling of iron in the surface ocean mediated by microbial iron(III)-binding ligands. Nature 413, 409-413. doi: 10.1038/35096545

Batchelli, S., Muller, F. L. L., Chang, K. C., and Lee, C. L. (2010). Evidence for strong but dynamic iron-humic colloidal associations in humic-rich coastal waters. Environ. Sci. Technol. 44, 8485-8490. doi: 10.1021/es101081c

Belkin, I. M., Cornillon, P. C., and Sherman, K. (2009). Fronts in large marine ecosystems. Prog. Oceanogr. 81, 223-236. doi: 10.1016/j.pocean.2009.04.015

Benner, R. (2011). Loose ligands and available iron in the ocean. Proc. Natl. Acad. Sci. U.S.A. 108, 893-894. doi: 10.1073/pnas.1018163108

Benner, R., Louchouarn, P., and Amon, R. M. W. (2005). Terrigenous dissolved organic matter in the Arctic Ocean and its transport to surface and deep waters of the North Atlantic. Global Biogeochem. Cycles 19:11. doi: 10.1029/2004GB002398 participation on data acquisition involved in this theory as well as the crew of the Southern Surveyor and the Chief scientist, Dr. Andrew Bowie, for the GEOTRACES P06 line. Finally, the authors are grateful for a stimulating SCOR funded Working Group (WG139) on organic ligands-a key control on trace metal biogeochemistry in the ocean.

\section{SUPPLEMENTARY MATERIAL}

The Supplementary Material for this article can be found online at: http://journal.frontiersin.org/article/10.3389/fmars. 2017.00019/full\#supplementary-material

Benner, R., Pakulski, J. D., McCarthy, M., Hedges, J. I., and Hatcher, P. G. (1992). Bulk chemical characteristics of dissolved organic-matter in the ocean. Science 255, 1561-1564. doi: 10.1126/science.255.5051.1561

Blanco-Ameijeiras, S., and Hassler, C. (2015). Iron limitation in the cyanobacteria synechococcus SP.: from gene expression to physiological responses. Eur. J. Phycol. 50:92.

Boiteau, R. M., Fitzsimmons, J. N., Repeta, D. J., and Boyle, E. A. (2013). Detection of iron ligands in seawater and marine cyanobacteria cultures by high-performance liquid chromatography-inductively coupled plasma-mass spectrometry. Anal. Chem. 85, 4357-4362. doi: 10.1021/ac3034568

Boiteau, R. M., Mende, D. R., Hawco, N. J., McIlvin, M. R., Fitzsimmons, J. N., Saito, M. A., et al. (2016a). Siderophore-based microbial adaptations to iron scarcity across the eastern Pacific Ocean. Proc. Nat. Acad. Sci. U.S.A. 113, 14237-14242. doi: 10.1073/pnas.1608594113

Boiteau, R. M., and Repeta, D. J. (2015). An extended siderophore suite from Synechococcus sp. PCC 7002 revealed by LC-ICPMS-ESIMS. Metallomics 7, 877-884. doi: 10.1039/C5MT00005J

Boiteau, R. M., Mende, D. R., Hawco, N. J., McIlvin, M. R., Fitzsimmons, J. N., Saito, M. A. et al. (2016b). Structural characterization of nickel and copper binding ligands along the US GEOTRACES eastern pacific zonal transect. Front. Mar. Sci. 3:243. doi: 10.3389/fmars.2016.00243

Bonnain, C., Breitbart, M., and Buck, K. N. (2016). The ferrojan horse hypothesis: iron-virus interactions in the ocean. Front. Mar. Sci. 3:82. doi: $10.3389 /$ fmars.2016.00082

Bordovsky, O. K. (1957). Humic substances in the deposits of the western part of the bering sea. Dokl. Akad. Nauk. SSSR 113, 157-160.

Bown, J., Boye, M., and Nelson, D. M. (2012). New insights on the role of organic speciation in the biogeochemical cycle of dissolved cobalt in the southeastern Atlantic and the Southern Ocean. Biogeosciences 9, 2719-2736. doi: 10.5194/bg-9-2719-2012

Boyd, P. W., Arrigo, K. R., Strzepek, R., and van Dijken, G. L. (2012). Mapping phytoplankton iron utilization: insights into southern ocean supply mechanisms. J. Geophys. Res. Oceans 117. doi: 10.1029/2011JC007726

Boyd, P. W., and Ellwood, M. J. (2010). The biogeochemical cycle of iron in the ocean. Nat. Geosci. 3, 675-682. doi: 10.1038/ngeo964

Boyd, P. W., Goldblatt, R. H., and Harrison, P. J. (1999). Mesozooplankton grazing manipulations during in vitro iron enrichment studies in the NE subarctic Pacific. Deep Sea Res. Part II Top. Stud. Oceanogr. 46, 2645-2668. doi: 10.1016/S0967-0645(99)00079-X

Boyd, P. W., Ibisanmi, E., Sander, S. G., Hunter, K. A., and Jackson, G. A. (2010). Remineralization of upper ocean particles: Implications for iron biogeochemistry. Limnol. Oceanogr. 55, 1271-1288. doi: 10.4319/lo.2010.55. 3.1271

Boyd, P. W., Law, C. S., Hutchins, D. A., Abraham, E. R., Croot, P. L., Ellwood, M., et al. (2005). FeCycle: attempting an iron biogeochemical budget from a mesoscale SF6 tracer experiment in unperturbed low iron waters. Global Biogeochem. Cycles 19:GB4S20. doi: 10.1029/2005GB002494

Boyd, P. W., and Tagliabue, A. (2015). Using the L* concept to explore controls on the relationship between paired ligand and dissolved iron concentrations in the ocean. Mar. Chem. 173, 52-66. doi: 10.1016/j.marchem.2014.12.003 
Boye, M., Nishioka, J., Croot, P., Laan, P., Timmermans, K. R., Strass, V. H., et al. (2010). Significant portion of dissolved organic Fe complexes in fact is Fe colloids. Mar. Chem. 122, 20-27. doi: 10.1016/j.marchem.2010.09.001

Boye, M., van den Berg, C. M. G., de Jong, J. T. M., Leach, H., Croot, P., and de Baar, H. J. W. (2001). Organic complexation of iron in the Southern Ocean. Deep Sea Res. Part I Oceanogr. Res. Pap. 48, 1477-1497. doi: 10.1016/S0967-0637(00)00099-6

Bruland, K. W., Rue, E. L., Smith, G. J., and DiTullio, G. R. (2005). Iron, macronutrients and diatom blooms in the Peru upwelling regime: brown and blue waters of Peru. Mar. Chem. 93, 81-103. doi: 10.1016/j.marchem. 2004.06.011

Buck, K. N., Lohan, M. C., Berger, C. J. M., and Bruland, K. W. (2007). Dissolved iron speciation in two distinct river plumes and an estuary: implications for riverine iron supply. Limnol. Oceanogr. 52, 843-855. doi: 10.4319/lo.2007.52.2.0843

Buck, K. N., Sohst, B., and Sedwick, P. N. (2015). The organic complexation of dissolved iron along the U.S. GEOTRACES (GA03) North Atlantic Section. Deep Sea Res. Part II Top. Stud. Oceanogr. 116, 152-165. doi: 10.1016/j.dsr2.2014.11.016

Bundy, R. M., Abdulla, H. A. N., Hatcher, P. G., Biller, D. V., Buck, K. N., and Barbeau, K. A. (2015). Iron-binding ligands and humic substances in the San Francisco Bay estuary and estuarine-influenced shelf regions of coastal California. Mar. Chem. 173, 183-194. doi: 10.1016/j.marchem.2014.11.005

Bundy, R. M., Biller, D. V., Buck, K. N., Bruland, K. W., and Barbeau, K. A. (2014). Distinct pools of dissolved iron-binding ligands in the surface and benthic boundary layer of the California Current. Limnol. Oceanogr. 59, 769-787. doi: 10.4319/lo.2014.59.3.0769

Bundy, R. M., Jiang, M., Carter, M., and Barbeau, K. A. (2016). Iron-binding ligands in the Southern California current system: mechanistic studies. Front. Mar. Sci. 3:27. doi: 10.3389/fmars.2016.00027

Burkhardt, B. G., Watkins-Brandt, K. S., Defforey, D., Paytan, A., and White, A. E. (2014). Remineralization of phytoplankton-derived organic matter by natural populations of heterotrophic bacteria. Mar. Chem. 163, 1-9. doi: 10.1016/j.marchem.2014.03.007

Butler, A., and Theisen, R. M. (2010). Iron(III)-siderophore coordination chemistry: Reactivity of marine siderophores. Coord. Chem. Rev. 254, 288-296. doi: 10.1016/j.ccr.2009.09.010

Caprara, S., Buck, K. N., Gerringa, L. J. A., Rijkenberg, M. J. A., and Monticelli, D. A. (2016). Compilation of iron speciation data for open oceanic waters. Front. Mar. Sci. 3:221 doi: 10.3389/fmars.2016.00221

Castruita, M., Shaked, Y., Elmegreen, L. A., Stiefel, E. I., and Morel, F. M. M. (2008). Availability of iron from iron-storage proteins to marine phytoplankton. Limnol. Oceanogr. 53, 890-899. doi: 10.4319/lo.2008.53.3.0890

Catala, T. S., Alvarez-Salgado, X. A., Otero, J., Iuculano, F., Companys, B., Horstkotte, B., et al. (2016). Drivers of fluorescent dissolved organic matter in the global epipelagic ocean. Limnol. Oceanogr. 61, 1101-1119. doi: $10.1002 / \operatorname{lno} .10281$

Catala, T. S., Reche, I., Fuentes-Lema, A., Romera-Castillo, C., Nieto-Cid, M., Ortega-Retuerta, E., et al. (2015). Turnover time of fluorescent dissolved organic matter in the dark global ocean. Nat. Commun. 6, 917-934. doi: $10.1038 /$ ncomms6986

Cheize, M., Sarthou, G., Croot, P. L., Bucciarelli, E., Baudoux, A.-C., and Baker, A. R. (2012). Iron organic speciation determination in rainwater using cathodic stripping voltammetry. Anal. Chim. Acta 736, 45-54. doi: 10.1016/j.aca.2012.05.011

Coale, K. H., Fitzwater, S. E., Gordon, R. M., Johnson, K. S., and Barber, R. T. (1996). Control of community growth and export production by upwelled iron in the equatorial Pacific Ocean. Nature 379, 621-624. doi: 10.1038/379621a0

Coble, P. G. (2007). Marine optical biogeochemistry: the chemistry of ocean color. Chem. Rev. 107, 402-418. doi: 10.1021/cr050350+

Cordero, O. X., Ventouras, L. A., DeLong, E. F., and Polz, M. F. (2012). Public good dynamics drive evolution of iron acquisition strategies in natural bacterioplankton populations. Proc. Natl. Acad. Sci. U.S.A. 109, 20059-20064. doi: 10.1073/pnas.1213344109

Croot, P. L., and Heller, M. I. (2012). The importance of kinetics and redox in the biogeochernical cycling of iron in the surface ocean. Front. Microbiol. 3:219. doi: 10.3389/fmicb.2012.00219
Croot, P. L., and Johansson, M. (2000). Determination of iron speciation by cathodic stripping voltammetry in seawater using the competing ligand 2-(2-thiazolylazo)-p-cresol (TAC). Electroanalysis 12, 565-576. doi: 10.1002/(SICI)1521-4109(200005)12:8<565::AID-ELAN565>3.0.CO;2-L

Cropp, R. A., Gabric, A. J., Levasseur, M., McTainsh, G. H., Bowie, A., Hassler, C. S., et al. (2013). The likelihood of observing dust-stimulated phytoplankton growth in waters proximal to the Australian continent. J. Mar. Syst. 117, 43-52. doi: 10.1016/j.jmarsys.2013.02.013

de Brouwer, J. F. C., Wolfstein, K., Ruddy, G. K., Jones, T. E. R., and Stal, L. J. (2005). Biogenic stabilization of intertidal sediments: the importance of extracellular polymeric substances produced by benthic diatoms. Microb. Ecol. 49, 501-512. doi: 10.1007/s00248-004-0020-z

Decho, A. W. (1990). Microbial exopolymer secretions in ocean environments - their role(s) in food webs and marine processes. Oceanogr. Mar. Biol. 28, 73-153.

DiTullio, G. R., Grebmeier, J. M., Arrigo, K. R., Lizotte, M. P., Robinson, D. H., Leventer, A., et al. (2000). Rapid and early export of Phaeocystis antarctica blooms in the Ross Sea, Antarctica. Nature 404, 595-598. doi: 10.1038/ 35007061

Duce, R. A., and Tindale, N. W. (1991). Atmospheric transport of iron and its deposition in the ocean. Limnol. Oceanogr. 36, 1715-1726. doi: 10.4319/lo.1991. 36.8.1715

Dupont, C. L., Moffett, J. W., Bidigare, R. R., and Ahner, B. A. (2006). Distributions of dissolved and particulate biogenic thiols in the subartic Pacific Ocean. Deep Sea Res. Part I Oceanogr. Res. Pap. 53, 1961-1974. doi: 10.1016/j.dsr.2006. 09.003

Dupont, C. L., Nelson, R. K., Bashir, S., Moffett, J. W., and Ahner, B. A. (2004). Novel copper-binding and nitrogen-rich thiols produced and exuded by Emiliania huxleyi. Limnol. Oceanogr. 49, 1754-1762. doi: 10.4319/lo.2004.49.5.1754

Ellwood, M. J., van den Berg, C. M. G., Boye, M., Veldhuis, M., de Jong, J. T. M., de Baar, H. J. W., et al. (2005). Organic complexation of cobalt across the Antarctic Polar Front in the Southern Ocean. Mar. Freshw. Res. 56, 1069-1075. doi: 10.1071/MF05097

Fishwick, M. P., Sedwick, P. N., Lohan, M. C., Worsfold, P. J., Buck, K. N., Church, T. M., et al. (2014). The impact of changing surface ocean conditions on the dissolution of aerosol iron. Global Biogeochem. Cycles 28, 1235-1250. doi: 10.1002/2014GB004921

Fitzsimmons, J. N., Bundy, R. M., Al-Subiai, S. N., Barbeau, K. A., and Boyle, E. A. (2015). The composition of dissolved iron in the dusty surface ocean: an exploration using size-fractionated iron-binding ligands. Mar. Chem. 173, 125-135. doi: 10.1016/j.marchem.2014.09.002

Gerringa, L. J. A., Rijkenberg, M. J. A., Schoemann, V., Laan, P., and de Baar, H. J. W. (2015). Organic complexation of iron in the West Atlantic Ocean. Mar. Chem. 177, 434-446. doi: 10.1016/j.marchem.2015.04.007

Gerringa, L. J. A., Rijkenberg, M. J. A., Thuroczy, C.-E., and Maas, L. R. M. (2014). A critical look at the calculation of the binding characteristics and concentration of iron complexing ligands in seawater with suggested improvements. Environ. Chem. 11, 114-136. doi: 10.1071/EN13072

Gerringa, L. J. A., Rijkenberg, M. J. A., Wolterbeek, H. T., Verburg, T. G., Boye, M., and de Baar, H. J. W. (2007). Kinetic study reveals weak Fe-binding ligand, which affects the solubility of Fe in the Scheldt estuary. Mar. Chem. 103, 30-45. doi: 10.1016/j.marchem.2006.06.002

Gledhill, M., Achterberg, E. P., Honey, D. J., Nielsdottir, M. C., and Rijkenberg, M. J. A. (2013). Distributions of particulate Heme b in the Atlantic and Southern Oceans-Implications for electron transport in phytoplankton. Global Biogeochem. Cycles 27, 1072-1082. doi: 10.1002/2013GB004639

Gledhill, M., and Buck, K. N. (2012). The organic complexation of iron in the marine environment: a review. Front. Microbiol. 3:69. doi: 10.3389/fmicb. 2012.00069

Gledhill, M., and van den Berg, C. M. G. (1994). Determination of complexation of iron(III) with natural organic complexing ligands in seawater using cathodic stripping voltammetry. Mar. Chem. 47, 41-54. doi: 10.1016/0304-4203(94)90012-4

Gobler, C. J., Donat, J. R., Consolvo, J. A., and Sanudo-Wilhelmy, S. A. (2002). Physicochemical speciation of iron during coastal algal blooms. Mar. Chem. 77, 71-89. doi: 10.1016/S0304-4203(01)00076-7 
Granger, J., and Price, N. M. (1999). The importance of siderophores in iron nutrition of heterotrophic marine bacteria. Limnol. Oceanogr. 44, 541-555. doi: 10.4319/lo.1999.44.3.0541

Guieu, C., Ridame, C., Pulido-Villena, E., Bressac, M., Desboeufs, K., and Dulac, F. (2014). Impact of dust deposition on carbon budget: a tentative assessment from a mesocosm approach. Biogeosciences 11, 5621-5635. doi: 10.5194/bg-11-5621-2014

Hansell, D. A. (2013). "Recalcitrant dissolved organic carbon fractions," in Annual Review of Marine Science, Vol. 5, eds C. A. Carlson and S. J. Giovannoni (Palo Alto, CA: Annual Reviews), 421-445.

Hansell, D. A., Carlson, C. A., and Schlitzer, R. (2012). Net removal of major marine dissolved organic carbon fractions in the subsurface ocean. Global Biogeochem. Cycles 26. doi: 10.1029/2011GB004069

Harvey, G. R., Boran, D. A., Chesal, L. A., and Tokar, J. M. (1983). The structure of marine fulvic and humic acids. Mar. Chem. 12, 119-132. doi: 10.1016/0304-4203(83)90075-0

Haselwandter, K. (1995). Mycorrhizal fungi - Siderophore production. Crit. Rev. Biotechnol. 15, 287-291. doi: 10.3109/07388559509147414

Hassler, C. S., Alasonati, E., Nichols, C. A. M., and Slaveykova, V. I. (2011a). Exopolysaccharides produced by bacteria isolated from the pelagic Southern Ocean - Role in Fe binding, chemical reactivity, and bioavailability. Mar. Chem. 123, 88-98. doi: 10.1016/j.marchem.2010.10.003

Hassler, C. S., Legiret, F. E., and Butler, E. C. V. (2013). Measurement of iron chemical speciation in seawater at $4^{\circ} \mathrm{C}$ : the use of competitive ligand exchange-adsorptive cathodic stripping voltammetry. Mar. Chem. 149, 63-73. doi: 10.1016/j.marchem.2012.12.007

Hassler, C. S., Ridgway, K. R., Bowie, A. R., Butler, E. C. V., Clementson, L. A., Doblin, M. A., et al. (2014). Primary productivity induced by iron and nitrogen in the Tasman Sea: an overview of the PINTS expedition. Mar. Freshw. Res. 65, 517-537. doi: 10.1071/MF13137

Hassler, C. S., Schoemann, V., Boye, M., Tagliabue, A., Rozmarynowycz, M., and McKay, R. M. L. (2012). "Iron bioavailability in the southern ocean," in Oceanography and Marine Biology: An Annual Review, Vol. 50, eds R. N. Gibson, R. J. A. Atkinson, J. D. M. Gordon, and R. N. Hughes (Palo Alto, CA: Annual Reviews), 1-63.

Hassler, C. S., Schoemann, V., Nichols, C. M., Butler, E. C. V., and Boyd, P. W. (2011b). Saccharides enhance iron bioavailability to Southern Ocean phytoplankton. Proc. Natl. Acad. Sci. U.S.A. 108, 1076-1081. doi: 10.1073/pnas. 1010963108

Hawkes, J. A., Gledhill, M., Connelly, D. P., and Achterberg, E. P. (2013). Characterisation of iron binding ligands in seawater by reverse titration. Anal. Chim. Acta 766, 53-60. doi: 10.1016/j.aca.2012.12.048

Heller, M. I., Gaiero, D. M., and Croot, P. L. (2013). Basin scale survey of marine humic fluorescence in the Atlantic: Relationship to iron solubility and $\mathrm{H} 2 \mathrm{O} 2$. Global Biogeochem. Cycles 27, 88-100. doi: 10.1029/2012GB004427

Hering, J. G., and Morel, F. M. M. (1989). Slow coordination reactions in seawater. Geochim. Cosmochim. Acta 53, 611-618. doi: 10.1016/0016-7037(89)90004-5

Hernlem, B. J., Vane, L. M., and Sayles, G. D. (1996). Stability constants for complexes of the siderophore desferrioxamine B with selected heavy metal cations. Inorgan. Chim. Acta 244, 179-184. doi: 10.1016/0020-1693(95)04780-8

Hertkorn, N., Benner, R., Frommberger, M., Schmitt-Kopplin, P., Witt, M., Kaiser, K., et al. (2006). Characterization of a major refractory component of marine dissolved organic matter. Geochim. Cosmochim. Acta 70, 2990-3010. doi: 10.1016/j.gca.2006.03.021

Hoagland, K. D., Rosowski, J. R., Gretz, M. R., and Roemer, S. C. (1993). Diatom extracellular polymeric substances - function, fine-structure, chemistry, and physiology. J. Phycol. 29, 537-566. doi: 10.1111/j.0022-3646.1993.00537.x

Hogle, S. L., Bundy, R. M., Blanton, J. M., Allen, E. E., and Barbeau, K. A.,(2016). Copiotrophic marine bacteria are associated with strong iron-binding ligand production during phytoplankton blooms. Limnol. Oceanogr. Lett. 1, 36-43. doi: $10.1002 / \mathrm{lol} 2.10026$

Hudson, R. J. M., and Morel, F. M. M. (1990). Iron transport in marine phytoplankton: kinetics of cellular and medium coordination reactions. Limnol. Oceanogr. 35, 1002-1020. doi: 10.4319/lo.1990.35.5.1002

Hudson, R. J. M., Rue, E. L., and Bruland, K. W. (2003). Modeling complexometric titrations of natural water samples. Environ. Sci. Technol. 37, 1553. doi: 10.1021/es025751a
Hunter, K. A., and Boyd, P. W. (2007). Iron-binding ligands and their role in the ocean biogeochemistry of iron. Environ. Chem. 4, 221-232. doi: 10.1071/EN07012

Hutchins, D. A., DiTullio, G. R., and Bruland, K. W. (1993). Iron and regenerated production: evidence for biological iron recycling in two marine environments. Limnol. Oceanogr. 38, 1242-1255. doi: 10.4319/lo.1993.38.6.1242

Ibisanmi, E., Sander, S. G., Boyd, P. W., Bowie, A. R., and Hunter, K. A. (2011). Vertical distributions of iron-(III) complexing ligands in the Southern Ocean. Deep Sea Res. Part II Top. Stud. Oceanogr. 58, 2113-2125. doi: 10.1016/j.dsr2.2011.05.028

Janse, I., vanRijssel, M., Gottschal, J. C., Lancelot, C., and Gieskes, W. W. C. (1996). Carbohydrates in the North Sea during spring blooms of Phaeocystis: a specific fingerprint. Aquat. Microbiol. Ecol. 10, 97-103. doi: 10.3354/ame010097

Jiao, N., Herndl, G. J., Hansell, D. A., Benner, R., Kattner, G., Wilhelm, S. W. et al. (2010). Microbial production of recalcitrant dissolved organic matter: long-term carbon storage in the global ocean. Nat. Rev. Microbiol. 8, 593-599. doi: $10.1038 /$ nrmicro2386

Jickells, T., Boyd, P. W., and Hunter, K. A. (2014). "Biogeochemical Impacts of Dust on the Global Carbon Cycle," in Mineral Dust - A Key Player in the Earth System, eds P. Knippertz and J.-B. W. Stuut (Heidelberg: Springer), 359-384.

Jickells, T. D., An, Z. S., Andersen, K. K., Baker, A. R., Bergametti, G., Brooks, N., et al. (2005). Global iron connections between desert dust, ocean biogeochemistry, and climate. Science 308, 67-71. doi: 10.1126/science.1105959

Johnson, K. S., Gordon, R. M., and Coale, K. H. (1997). What controls dissolved iron concentrations in the world ocean? Mar. Chem. 57, 137-161. doi: 10.1016/S0304-4203(97)00043-1

Kirchman, D. L., Moran, X. A. G., and Ducklow, H. (2009). Microbial growth in the polar oceans - role of temperature and potential impact of climate change. Nat. Rev. Microbiol. 7, 451-459. doi: 10.1038/nrmicro2115

Kleint, C., Hawkes, J. A., Sander, S. G., and Koschinsky, A. (2016). Voltammetric investigation of hydrothermal iron speciation. Front. Mar. Sci. 3:75. doi: $10.3389 /$ fmars.2016.00075

Koopal, L. K., Saito, T., Pinheiro, J. P., and van Riemsdijk, W. H. (2005). Ion binding to natural organic matter: general considerations and the NICA-Donnan model. Colloids Surf. A Physicochem. Eng. Asp. 265, 40-54. doi: 10.1016/j.colsurfa.2004.11.050

Krachler, R., Krachler, R. F., Wallner, G., Hann, S., Laux, M., Cervantes Recalde, M. F., et al. (2015). River-derived humic substances as iron chelators in seawater. Mar. Chem. 174, 85-93. doi: 10.1016/j.marchem.2015.05.009

Kraemer, S. M., Butler, A., Borer, P., and Cervini-Silva, J. (2005). "Siderophores and the dissolution of iron-bearing minerals in marine systems," in Molecular Geomicrobiology, eds J. E. Banfield, J. CerviniSilva, and K. H. Nealson (Palo Alto, CA: Mineralogical Society of America), 53-84.

Kraemer, S. M., Crowley, D. E., and Kretzschmar, R. (2006). Geochemical aspects of phytosiderophore-promoted iron acquisition by plants. Adv. Agron. 91, 1-46. doi: 10.1016/S0065-2113(06)91001-3

Kraemer, S. M., Duckworth, O. W., Harrington, J. M., and Schenkeveld, W. D. C. (2015). Metallophores and trace metal biogeochemistry. Aquat. Geochem. 21, 159-195. doi: 10.1007/s10498-014-9246-7

Kuma, K., Katsumoto, A., Kawakami, H., Takatori, F., and Matsunaga, K. (1998). Spatial variability of $\mathrm{Fe}(\mathrm{III})$ hydroxide solubility in the water column of the northern North Pacific Ocean. Deep Sea Res. Part I Oceanogr. Res. Pap. 45, 91-113. doi: 10.1016/S0967-0637(97)00067-8

Kwon, E. Y., Kim, G., Primeau, F., Moore, W. S., Cho, H. M., DeVries, T., et al. (2014). Global estimate of submarine groundwater discharge based on an observationally constrained radium isotope model. Geophys. Res. Lett. 41, 8438-8444. doi: 10.1002/2014GL061574

Laglera, L. M., Battaglia, G., and van den Berg, C. M. G. (2007). Determination of humic substances in natural waters by cathodic stripping voltammetry of their complexes with iron. Anal. Chim. Acta 599, 58-66. doi: 10.1016/j.aca.2007.07.059

Laglera, L. M., and van den Berg, C. M. G. (2009). Evidence for geochemical control of iron by humic substances in seawater. Limnol. Oceanogr. 54, 610-619. doi: 10.4319/lo.2009.54.2.0610

Lannuzel, D., Grotti, M., Abelmoschi, M. L., and van der Merwe, P. (2015). Organic ligands control the concentrations of dissolved iron in Antarctic sea ice. Mar. Chem. 174, 120-130. doi: 10.1016/j.marchem.2015.05.005 
Lannuzel, D., Schoemann, V., de Jong, J., Chou, L., Delille, B., Becquevort, S., et al. (2008). Iron study during a time series in the western Weddell pack ice. Mar. Chem. 108, 85-95. doi: 10.1016/j.marchem.2007.10.006

Lannuzel, D., Schoemann, V., de Jong, J., Tison, J. L., and Chou, L. (2007). Distribution and biogeochemical behaviour of iron in the East Antarctic sea ice. Mar. Chem. 106, 18-32. doi: 10.1016/j.marchem.2006.06.010

Laurenceau-Cornec, E. C., Trull, T. W., Davies, D. M., De La Rocha, C. L., and Blain, S. (2015). Phytoplankton morphology controls on marine snow sinking velocity. Mar. Ecol. Prog. Ser. 520, 35-56. doi: 10.3354/meps11116

Leal, M. F. C., Vasconcelos, M. T. S. D., and van den Berg, C. M. G. (1999). Copper-induced release of complexing ligands similar to thiols by Emiliania huxleyi in seawater cultures. Limnol. Oceanogr. 44, 1750-1762. doi: 10.4319/lo.1999.44.7.1750

Lechtenfeld, O. J., Kattner, G., Flerus, R., McCallister, S. L., Schmitt-Kopplin, P., and Koch, B. P. (2014). Molecular transformation and degradation of refractory dissolved organic matter in the Atlantic and Southern Ocean. Geochim. Cosmochim. Acta 126, 321-337. doi: 10.1016/j.gca.2013.11.009

Letscher, R. T., Hansell, D. A., and Kadko, D. (2011). Rapid removal of terrigenous dissolved organic carbon over the Eurasian shelves of the Arctic Ocean. Mar. Chem. 123, 78-87. doi: 10.1016/j.marchem.2010.10.002

Lin, H., and Twining, B. S. (2012). Chemical speciation of iron in Antarctic waters surrounding free-drifting icebergs. Mar. Chem. 128, 81-91. doi: 10.1016/j.marchem.2011.10.005

Liu, H. B., Laws, E. A., Villareal, T. A., and Buskey, E. J. (2001). Nutrientlimited growth of Aureoumbra lagunensis (Pelagophyceae), with implications for its capability to outgrow other phytoplankton species in phosphatelimited environments. J. Phycol. 37, 500-508. doi: 10.1046/j.1529-8817. 2001.037004500.x

MacRellis, H. M., Trick, C. G., Rue, E. L., Smith, G., and Bruland, K. W. (2001). Collection and detection of natural iron-binding ligands from seawater. Mar. Chem. 76, 175-187. doi: 10.1016/S0304-4203(01)00061-5

Mahowald, N. M., Baker, A. R., Bergametti, G., Brooks, N., Duce, R. A., Jickells, T. D., et al. (2005). Atmospheric global dust cycle and iron inputs to the ocean. Global Biogeochem. Cycles 19. doi: 10.1029/2004GB002402

Maldonado, M. T., Hughes, M. P., Rue, E. L., and Wells, M. L. (2002). The effect of $\mathrm{Fe}$ and $\mathrm{Cu}$ on growth and domoic acid production by Pseudo-nitzschia multiseries and Pseudo-nitzschia australis. Limnol. Oceanogr. 47, 515-526. doi: 10.4319/lo.2002.47.2.0515

Maldonado, M. T., Strzepek, R. F., Sander, S., and Boyd, P. W. (2005). Acquisition of iron bound to strong organic complexes, with different $\mathrm{Fe}$ binding groups and photochemical reactivities, by plankton communities in Fe-limited subantarctic waters. Global Biogeochem. Cycles 19. doi: 10.1029/2005GB002481

Martino, M., Turner, A., and Nimmo, M. (2004). Distribution, speciation and particle-water interactions of nickel in the Mersey Estuary, UK. Mar. Chem. 88,161-177. doi: 10.1016/j.marchem.2004.03.007

Mawji, E., Gledhill, M., Milton, J. A., Tarran, G. A., Ussher, S., Thompson, A., et al. (2008). Hydroxamate siderophores: occurrence and importance in the Atlantic Ocean. Environ. Sci. Technol. 42, 8675-8680. doi: 10.1021/es801884r

Mawji, E., Gledhill, M., Milton, J. A., Zubkov, M. V., Thompson, A., Wolff, G. A., et al. (2011). Production of siderophore type chelates in Atlantic Ocean waters enriched with different carbon and nitrogen sources. Mar. Chem. 124, 90-99. doi: 10.1016/j.marchem.2010.12.005

Medeiros, P. M., Seidel, M., and Niggemann, J. (2016). A novel molecular approach for tracing terrigenous dissolved organic matter into the deep ocean. Glob. Biogeochem. Cyles. 30, 689-699. doi: 10.1002/2015GB005320

Melton, E. D., Swanner, E. D., Behrens, S., Schmidt, C., and Kappler, A. (2014). The interplay of microbially mediated and abiotic reactions in the biogeochemical Fe cycle. Nat. Rev. Microbiol. 12, 797-808. doi: 10.1038/nrmicro3347

Moore, J. K., Lindsay, K., Doney, S. C., Long, M. C., and Misumi, K. (2013). Marine ecosystem dynamics and biogeochemical cycling in the community earth system model [cesm1(bgc)]: comparison of the 1990s with the 2090s under the RCP4.5 and RCP8.5 Scenarios. J. Clim. 26, 9291-9312. doi: 10.1175/JCLI-D-12-00566.1

Moran, M. A., Kujawinski, E. B., Stubbins, A., Fatland, R., Aluwihare, L. I., Buchan, A., et al. (2016). Deciphering ocean carbon in a changing world. Proc. Natl. Acad. Sci. U.S.A. 113, 3143-3151. doi: 10.1073/pnas.1514645113

Myklestad, S. (1977). Production of carbohydrates by marine planktonic diatoms. 2. Influence of N-P ratio in growth medium on assimilation ratio, growth-rate, and production of cellular and extracellular carbohydrates by Chaetoceros-Affiniis var Willei (Gran) Hustedt and Skeletonema-costatum (Grev) Cleve. J. Exp. Mar. Biol. Ecol. 29, 161-179. doi: 10.1016/0022-0981(77) 90046-6

Nichols, C. A. M., Garon, S., Bowman, J. P., Raguenes, G., and Guezennec, J. (2004). Production of exopolysaccharides by Antarctic marine bacterial isolates. J. Appl. Microbiol. 96, 1057-1066. doi: 10.1111/j.13652672.2004.02216.x

Nichols, C. A. M., Guezennec, J., and Bowman, J. P. (2005). Bacterial exopolysaccharides from extreme marine environments with special consideration of the southern ocean, sea ice, and deep-sea hydrothermal vents: a review. Mar. Biotechnol. 7, 253-271. doi: 10.1007/s10126-004-5118-2

Norman, L. (2014). The Role of Natural Organic Ligands in Transformations of Iron Chemistry in Seawater and Their Effect on the Bioavailability or Iron to Marine Phytoplankton. Ph.D. thesis, School of the Environment, University of Technology, Sydney.

Norman, L., Worms, I. A. M., Angles, E., Bowie, A. R., Nichols, C. M., Ninh Pham, A., et al. (2015). The role of bacterial and algal exopolymeric substances in iron chemistry. Mar. Chem. 173, 148-161. doi: 10.1016/j.marchem.2015.03.015

Nunn, B. L., Faux, J. F., Hippmann, A. A., Maldonado, M. T., Harvey, H. R., Goodlett, D. R., et al. (2013). Diatom proteomics reveals unique acclimation strategies to mitigate Fe limitation. PLoS ONE 8:e75653. doi: 10.1371/journal.pone.0075653

Ogawa, H., Amagai, Y., Koike, I., Kaiser, K., and Benner, R. (2001). Production of refractory dissolved organic matter by bacteria. Science 292, 917-920. doi: 10.1126/science.1057627

Orellana, M. V., and Hansell, D. A. (2012). Ribulose-1,5-bisphosphate carboxylase/oxygenase (RuBisCO): A long-lived protein in the deep ocean. Limnol. Oceanogr. 57, 826-834. doi: 10.4319/lo.2012.57.3.0826

Orellana, M. V., Lessard, E. J., Dycus, E., Chin, W. C., Foy, M. S., and Verdugo, P. (2003). Tracing the source and fate of biopolymers in seawater: application of an immunological technique. Mar. Chem. 83, 89-99. doi: 10.1016/S0304-4203(03)00098-7

Ozturk, M., Croot, P. L., Bertilsson, S., Abrahamsson, K., Karlson, B., David, R., et al. (2004). Iron enrichment and photoreduction of iron under UV and PAR in the presence of hydroxycarboxylic acid: implications for phytoplankton growth in the Southern Ocean. Deep Sea Res. Part II Top. Stud. Oceanogr. 51, 2841-2856. doi: 10.1016/j.dsr2.2000.10.001

Pakulski, J. D., and Benner, R. (1994). Abundance and distribution of carbohydrates in the ocean. Limnol. Oceanogr. 39, 930-940. doi: 10.4319/ lo.1994.39.4.0930

Panagiotopoulos, C., and Sempere, R. (2005). Analytical methods for the determination of sugars in marine samples: a historical perspective and future directions. Limnol. Oceanogr. Methods 3, 419-454. doi: 10.4319/lom.2005.3.419

Paris, R., and Desboeufs, K. V. (2013). Effect of atmospheric organic complexation on iron-bearing dust solubility. Atmos. Chem. Phys. 13, 4895-4905. doi: 10.5194/acp-13-4895-2013

Ploug, H., Grossart, H. P., Azam, F., and Jorgensen, B. B. (1999). Photosynthesis, respiration, and carbon turnover in sinking marine snow from surface waters of Southern California Bight: implications for the carbon cycle in the ocean. Mar. Ecol. Prog. Ser. 179, 1-11. doi: 10.3354/meps179001

Poorvin, L., Sander, S. G., Velasquez, I., Ibisanmi, E., LeCleir, G. R., and Wilhelm, S. W. (2011). A comparison of Fe bioavailability and binding of a catecholate siderophore with virus-mediated lysates from the marine bacterium Vibrio alginolyticus PWH3a. J. Exp. Mar. Biol. Ecol. 399, 43-47. doi: $10.1016 /$ j.jembe.2011.01.016

Powell, R. T., and Wilson-Finelli, A. (2003). Importance of organic Fe complexing ligands in the Mississippi River plume. Estuar. Coast. Shelf Sci. 58, 757. doi: 10.1016/S0272-7714(03)00182-3

Price, N. M., and Morel, F. M. M. (1998). "Biological cycling of iron in the ocean," in Metal Ions in Biological Systems, eds A. Sigel and H. Sigel (New York, NY: Marcel Dekker) 1-36.

Primeau, F. W., and Holzer, M. (2006). The ocean's memory of the atmosphere: residence-time and ventilation-rate distributions of water masses. J. Phys. Oceanogr. 36, 1439-1456. doi: 10.1175/JPO2919.1

Reid, R. T., Live, D. G., Faulkner, D. J., and Butler, A. (1993). A siderophore from a marine bacterium with an exceptional ferric ion affinity constant. Nature 366, 455-458. doi: $10.1038 / 366455 \mathrm{a} 0$ 
Repeta, D. J., and Aluwihare, L. I. (2006). Radiocarbon analysis of neutral sugars in high-molecular-weight dissolved organic carbon: implications for organic carbon cycling. Limnol. Oceanogr. 51, 1045-1053. doi: 10.4319/lo.2006.51.2.1045

Repeta, D., Boiteau, R. M., Mende, D. R., and DeLong, E. F. (2016). "Microbes Adapt to Iron Scarcity through Siderophore Production across the Eastern Tropical Pacific," in Ocean Science Meeting, AGU/ASLO/TOS (New Orleans, LA).

Resing, J. A., Sedwick, P. N., German, C. R., Jenkins, W. J., Moffett, J. W., Sohst, B. M., et al. (2015). Basin-scale transport of hydrothermal dissolved metals across the South Pacific Ocean. Nature 523, 200-U140. doi: 10.1038/nature14577

Rue, E., and Bruland, K. (2001). Domoic acid binds iron and copper: a possible role for the toxin produced by the marine diatom Pseudo-nitzschia. Mar. Chem. 76, 127-134. doi: 10.1016/S0304-4203(01)00053-6

Rue, E. L., and Bruland, K. W. (1995). Complexation of iron(III) by natural organic-ligands in the central north pacific as determined by a new competitive ligand equilibration adsorptive cathodic stripping voltammetric method. Mar. Chem. 50, 117-138. doi: 10.1016/0304-4203(95)00031-L

Sander, S. G., and Koschinsky, A. (2011). Metal flux from hydrothermal vents increased by organic complexation. Nat. Geosci. 4, 1-6. doi: 10.1038/ngeo1088

Sarthou, G., Vincent, D., Christaki, U., Obernosterer, I., Timmermans, K. R., and Brussaard, C. P. D. (2008). The fate of biogenic iron during a phytoplankton bloom induced by natural fertilisation: Impact of copepod grazing. Deep Sea Res. Part II Top. Stud. Oceanogr. 55, 734-751. doi: 10.1016/j.dsr2.2007.12.033

Schlosser, C., De La Rocha, C. L., Streu, P., and Croot, P. L. (2012). Solubility of iron in the Southern Ocean. Limnol. Oceanogr. 57, 684-697. doi: 10.4319/lo.2012.57.3.0684

Seidel, M., Yager, P. L., Ward, N. D., Carpenter, E. J., Gomes, H. R., Krusche, A. V., et al. (2015). Molecular-level changes of dissolved organic matter along the Amazon River-to-ocean continuum. Mar. Chem. 177, 218-231. doi: 10.1016/j.marchem.2015.06.019

Sholkovitz, E. R., Boyle, E. A., and Price, N. B. (1978). Removal of dissolved humic acids and iron during estuarine mixing. Earth Planet. Sci. Lett. 40, 130-136. doi: $10.1016 / 0012-821 \mathrm{X}(78) 90082-1$

Stolpe, B., and Hassellov, M. (2010). Nanofibrils and other colloidal biopolymers binding trace elements in coastal seawater: significance for variations in element size distributions. Limnol. Oceanogr. 55, 187-202. doi: 10.4319/lo.2010.55.1.0187

Stolpe, B., Zhou, Z. Z., Guo, L. D., and Shiller, A. M. (2014). Colloidal size distribution of humic- and protein-like fluorescent organic matter in the northern Gulf of Mexico. Mar. Chem. 164, 25-37. doi: 10.1016/j.marchem. 2014.05.007

Strzepek, R. F., Maldonado, M. T., Higgins, J. L., Hall, J., Safi, K., Wilhelm, S. W., et al. (2005). Spinning the "Ferrous Wheel": The importance of the microbial community in an iron budget during the FeCycle experiment. Global Biogeochem. Cycles 19. doi: 10.1029/2005GB002490

Tagliabue, A., Williams, R. G., Rogan, N., Achterberg, E. P., and Boyd, P. W. (2014). A ventilation-based framework to explain the regenerationscavenging balance of iron in the ocean. Geophys. Res. Lett. 41, 7227-7236. doi: 10.1002/2014GL061066

Tanaka, K., Kuma, K., Hamasaki, K., and Yamashita, Y. (2014). Accumulation of humic-like fluorescent dissolved organic matter in the Japan Sea. Sci. Rep. 4. doi: $10.1038 /$ srep 05292

Trick, C. G., Wilhelm, S. W., and Brown, C. M. (1995). Alterations in cell pigmentation, protein expression, and photosynthetic capacity of the cyanobacterium Oscillatoria tenuis grown under low iron conditions. Can. J. Microbiol. 41, 1117-1123. doi: 10.1139/m95-155

Trimborn, S., Hoppe, C. J. M., Taylor, B. B., Bracher, A., and Hassler, C. (2015). Physiological characteristics of open ocean and coastal phytoplankton communities of Western Antarctic Peninsula and Drake Passage waters. Deep Sea Res. Part I Oceanogr. Res. Pap. 98, 115-124. doi: 10.1016/j.dsr.2014. 12.010

van den Berg, C. M. G. (1995). Evidence for organic complexation of iron in seawater. Mar. Chem. 50, 139-157. doi: 10.1016/0304-4203(95) 00032-M van der Merwe, P., Lannuzel, D., Nichols, C. A. M., Meiners, K., Heil, P., Norman, L., et al. (2009). Biogeochemical observations during the winter-spring transition in East Antarctic sea ice: evidence of iron and exopolysaccharide controls. Mar. Chem. 115, 163-175. doi: 10.1016/j.marchem.2009.08.001

Velasquez, I., Ibisanmi, E., Maas, E. W., Boyd, P. W., Nodder, S., and Sander, S. G. (2016). Ferrioxamine siderophores detected amongst iron binding ligands produced during the remineralization of marine particles. Front. Mar. Sci. 3:172. doi: $10.3389 /$ fmars.2016.00172

Velasquez, I., Nunn, B. L., Ibisanmi, E., Goodlett, D. R., Hunter, K. A., and Sander, S. G. (2011). Detection of hydroxamate siderophores in coastal and Sub-Antarctic waters off the South Eastern Coast of New Zealand. Mar. Chem. 126, 97-107. doi: 10.1016/j.marchem.2011.04.003

Verdugo, P., Alldredge, A. L., Azam, F., Kirchman, D. L., Passow, U., and Santschi, P. H. (2004). The oceanic gel phase: a bridge in the DOM-POM continuum. Mar. Chem. 92, 67-85. doi: 10.1016/j.marchem.2004.06.017

Völker, C., and Tagliabue, A. (2015). Modeling organic iron-binding ligands in a three-dimensional biogeochemical ocean model. Mar. Chem. 173, 67-77. doi: 10.1016/j.marchem.2014.11.008

Volker, C., and Wolf-Gladrow, D. A. (1999). Physical limits on iron uptake mediated by siderophores or surface reductases. Mar. Chem. 65, 227-244. doi: 10.1016/S0304-4203(99)00004-3

Vraspir, J. M., and Butler, A. (2009). Chemistry of marine ligands and siderophores. Ann. Rev. Mar. Sci. 1, 43-63. doi: 10.1146/annurev.marine.010908.163712

Wagener, T., Guieu, C., Losno, R., Bonnet, S., and Mahowald, N. (2008). Revisiting atmospheric dust export to the Southern Hemisphere ocean: biogeochemical implications. Global Biogeochem. Cycles 22. doi: 10.1029/2007gb002984

Walsh, M. J., Goodnow, S. D., Vezeau, G. E., Richter, L. V., and Ahner, B. A. (2015). Cysteine enhances bioavailability of copper to marine phytoplankton. Environ. Sci. Technol. 49, 12145-12152. doi: 10.1021/acs.est.5b02112

Waska, H., Dittmar, T., and Koschinsky, A. (2016). Fe- and Cu-complex formation with artificial ligands investigated by ultra-high resolution Fourier-transform ion cyclotron resonance mass spectrometry (FT-ICR-MS): implications for natural metal-organic complex studies. Front. Mar. Sci. 3:119. doi: $10.3389 /$ fmars.2016.00119

Westrich, J. R., Ebling, A. M., Landing, W. M., Joyner, J. L., Kemp, K. M., Griffin, D. W., et al. (2016). Saharan dust nutrients promote Vibrio bloom formation in marine surface waters. Proc. Natl. Acad. Sci. U.S.A. 113, 5964-5969. doi: $10.1073 /$ pnas. 1518080113

Wilhelm, S. W., and Trick, C. G. (1994). Iron-limited growth of cyanobacteria multiple siderophore production is a common response. Limnol. Oceanogr. 39, 1979-1984. doi: 10.4319/lo.1994.39.8.1979

Willey, J. D., Kieber, R. J., Eyman, M. S., and Avery, G. B. (2000). Rainwater dissolved organic carbon: concentrations and global flux. Global Biogeochem. Cycles 14, 139-148. doi: 10.1029/1999GB900036

Witter, A. E., Hutchins, D. A., Butler, A., and Luther, G. W. (2000). Determination of conditional stability constants and kinetic constants for strong model Fe-binding ligands in seawater. Mar. Chem. 69, 1-17. doi: 10.1016/S0304-4203(99)00087-0

Yamashita, Y., Cory, R. M., Nishioka, J., Kuma, K., Tanoue, E., and Jaffe, R. (2010). Fluorescence characteristics of dissolved organic matter in the deep waters of the Okhotsk Sea and the northwestern North Pacific Ocean. Deep Sea Res. Part II Top. Stud. Oceanogr. 57, 1478-1485. doi: 10.1016/j.dsr2.2010.02.016

Yang, R., and van den Berg, C. M. (2009). Metal complexation by humic substances in seawater. Environ. Sci. Technol. 43, 7192-7197. doi: 10.1021/es900173w

Conflict of Interest Statement: The authors declare that the research was conducted in the absence of any commercial or financial relationships that could be construed as a potential conflict of interest.

Copyright (c) 2017 Hassler, van den Berg and Boyd. This is an open-access article distributed under the terms of the Creative Commons Attribution License (CC BY). The use, distribution or reproduction in other forums is permitted, provided the original author(s) or licensor are credited and that the original publication in this journal is cited, in accordance with accepted academic practice. No use, distribution or reproduction is permitted which does not comply with these terms. 